\title{
Resurrection of the sea pen genus Ptilella Gray, 1870 and description of Ptilella grayi n. sp. from the NE Atlantic (Octocorallia: Pennatulacea)
}

\author{
Francisco J. García-Cárdenas ${ }^{1}$, Jim Drewery ${ }^{2}$, Pablo J. López-González ${ }^{1}$ \\ ${ }^{1}$ Biodiversidad y Ecología Acuática, Departamento de Zoología, Facultad de Biología, Universidad de Sevilla, \\ Reina Mercedes 6, 41012 Sevilla, Spain. \\ (FJG-C) (corresponding author) E-mail: frangarca@us.es. ORCID-iD: https://orcid.org/0000-0002-1503-9552 \\ (PJL-G) E-mail: pjlopez@us.es. ORCID-iD: https://orcid.org/0000-0002-7348-6270 \\ ${ }^{2}$ Marine Scotland Science, Marine Laboratory, 375 Victoria Road, Aberdeen, Scotland, UK, AB11 9DB. \\ (JD) E-mail: jim.drewery @ gov.scot. ORCID-iD: https://orcid.org/0000-0003-4308-1798
}

\begin{abstract}
Summary: The order Pennatulacea covers a group of specialized and morphologically distinct octocorals found in all oceans from intertidal areas to more than $6000 \mathrm{~m}$ in depth. Sea pens constitute an important structural component in marine softbottom communities by increasing the complexity of these environments. Despite being both morphologically distinctive and ecologically important, the taxonomy and systematics of sea pens is still poorly understood. Recent molecular studies have shown the existence of convergent morphological features, making the current familial distribution of genera unstable. The genus Pennatula Linnaeus, 1758 was one of the first described octocoral genera. It is the type genus of its family, Pennatulidae. Colonies of this genus have a characteristic morphology. Recent sampling efforts in the northeastern Atlantic have provided a number of colonies initially attributable to the genus Pennatula. Both morphological and molecular ( $m t M u t S$, CoxI and $28 S$ genes) study of this material supports the polyphyletic nature of this genus and the need to resurrect the genus Ptilella Gray, 1870 to accommodate these and other species. A new species, Ptilella grayi $\mathrm{n}$. sp., is described and illustrated. The species Pennatula bayeri is proposed to be a junior synonym of Pennatula bellissima (here also considered in the genus Ptilella).
\end{abstract}

Keywords: NE Atlantic; Pennatulacea; Ptilella grayi; sea pen; new species.

Resurrección del género de pluma de mar Ptilella Gray, 1870, y descripción de Ptilella grayi n. sp. del Atlántico NE (Octocorallia: Pennatulacea)

Resumen: El orden Pennatulacea abarca a un grupo de octocorales especializados y morfológicamente diferenciados, distribuidos por todos los océanos, desde las zonas intermareales hasta más de 6000 metros de profundidad. Las plumas de mar constituyen un importante componente estructural en las comunidades marinas de fondo blando, incrementando la complejidad de estos ambientes. A pesar de ser característicos morfológicamente, e importantes ecológicamente, la taxonomía y la sistemática de las plumas de mar es aún pobremente conocida. Recientes estudios moleculares han mostrado la existencia de características morfológicas convergentes, haciendo inestable la actual distribución familiar de los géneros. El género Pennatula Linnaeus, 1758, fue uno de los primeros géneros de octocorales descritos. Es el género tipo de su familia, Pennatulidae. Las colonias de este género tienen una morfología característica. Los recientes esfuerzos de muestreo en el noreste Atlántico han proporcionado un número de colonias inicialmente atribuibles al género Pennatula. Tanto el estudio morfológico como molecular (genes $m t M u t S$, Coxl y 28S) de este material respaldan la naturaleza polifilética de este género, y la necesidad de resucitar al género Ptilella Gray, 1870 para acomodar a éstas y otras especies. Una nueva especie, Ptilella grayi n. sp., es descrita e ilustrada. La especie Pennatula bayeri es propuesta como sinónimo reciente de Pennatula bellissima (aquí también considerada en el género Ptilella).

Palabras clave: noreste Atlántico; Pennatulacea; Ptilella grayi; pluma de mar; nueva especie.

Citation/Como citar este artículo: García-Cárdenas F.J., Drewery J., López-González P.J. 2019. Resurrection of the sea pen genus Ptilella Gray, 1870 and description of Ptilella grayi n. sp. from the NE Atlantic (Octocorallia: Pennatulacea). Sci. Mar. 83(3): 261-276. https://doi.org/10.3989/scimar.04845.26A

LSID: http://zoobank.org/urn:1sid:zoobank.org:pub:2E460301-B5FC-43E5-8393-9D803E034D02

Editor: D. Vaqué.

Received: August 22, 2018. Accepted: June 7, 2019. Published: July 9, 2019:

Copyright: (c) 2019 CSIC. This is an open-access article distributed under the terms of the Creative Commons Attribution 4.0 International (CC BY 4.0) License. 


\section{INTRODUCTION}

The anthozoan fauna from deep-sea zones is still poorly known, despite recent international efforts having improved our general knowledge of the diversity and ecology of deep-sea benthic communities. Sea pens are a group of specialized and morphologically distinct octocorals found in all oceans, from intertidal areas to more than $6000 \mathrm{~m}$ in depth (Bayer 1956, Williams 2011). The order Pennatulacea includes more than 200 species in 35 genera and 14 families (López-González et al. 2001, López-González and Williams 2002, Williams 2015). Sea pens constitute an important structural component in marine soft-bottoms communities, increasing the complexity of these environments in a role similar to that of other coral groups such as gorgonians and scleractinians, which are typically found on a more rocky substrata (Sale 1977, Done 1999). The ecological importance of the recently discovered rockpens (Williams and Alderslade 2011) is yet to be evaluated, although they could potentially also contribute similarly to scleractinians and gorgonians by providing yet another environmental niche in rocky seabeds. Moreover, it has been demonstrated that sea pens are often used as a refuge or nurseries for demersal fauna (Sammarco and Coll 1992, Baillon et al. 2012). The ecological importance of sea pen beds is internationally recognized, with these being included in red lists of marine environments threatened by anthropogenic activities (see OSPAR Commission 2010).

Among sea pens, the genus Pennatula Linnaeus, 1758 was one of the first described octocoral genera. It is the type genus of its own family, Pennatulidae. Colonies assigned to this genus exhibit a high consistency of morphological characters, being typically pinnate (feather-like) in shape, with well-developed polyp leaves, with polymorphic zooids. Autozooids arranged along the ventral edge of the polyp leaves, as well as siphonozooids and sometimes mesozooids at the base of the polyp leaves or on the rachis, and with the sclerites along the colony mainly as three-flanged needles (see Kükenthal 1915, Williams 1995a).

Recent molecular studies in octocorals have identified the order Pennatulacea as a monophyletic group (McFadden et al. 2006, Dolan et al. 2013, Kushida and Reimer 2018). However, the monophyly of the various supra-familial and familial pennatulacean groupings that have been proposed historically has recently been questioned by these same molecular studies (McFadden et al. 2006, Dolan et al. 2013, Kushida and Reimer 2018).

Although Dolan et al. (2013: 615) does not reject the possible monophyly of some genera such as Kophobelemnon, Pennatula is clearly identified as polyphyletic, suggesting the need for a redefinition of this genus. This will provide a solution to the current problem that morphological criteria used to identify members of the genus Pennatula have been found to only poorly resolve their phylogenetic relationships when compared with analysis based on DNA sequence data (see Dolan et al. 2013: 614-615). More recently (Kushida and Reimer 2018), the genera Umbellula, Pennatula and Kophobelemnon were also shown as polyphyletic groups. When a polyphyletic or paraphyletic group is detected from molecular evidence, morphological characters are re-examined to identify those characters concordant with the molecular clades, and to solve potential homoplastic situations according to nomenclatural rules (Lowther et al. 2004, Fleck et al. 2008). The delimitation of monophyletic groupings and the establishment of their relationships is a common problem in evolutionary biology research (e.g. Wheeler and Nixon 1990, Crisp and Chandler 1996, Brummitt 2002, among many others).

The current conception of the cosmopolitan genus Pennatula includes at least 14 valid species (Williams 2011). However, some of these species have descriptions based on single and frequently poorly preserved specimens, or on specimens lacking those characteristics currently in use for reliable diagnosis (Kölliker 1880, Kükenthal 1915, Hickson 1916).

In recent years the benthic component of a range of surveys carried out in the northeastern Atlantic by Marine Scotland Science (MSS) has provided an interesting collection of pennatulaceans, many of which have formed the basis for this study. The material examined was collected over the period 2007-2016 during various demersal trawl surveys carried out by MSS on board the research vessel MRV Scotia.

In this study, certain colonies initially attributed to two chromatic forms of the northeastern Atlantic species Pennatula grandis Ehrenberg, 1834 were collected. However, detailed morphological and molecular study of these specimens highlighted differences, suggesting further consideration of the current genus Pennatula as a polyphyletic grouping. The genus placement of Ehrenberg's species and the need for the resurrection of a forgotten sea pen genus is discussed, and a new species is proposed.

\section{METHODS}

\section{Sampling}

The material studied was collected using a large demersal trawl (supplemented occasionally with a small ground gear net that was deployed directly underneath the main net deployed) on banks and terraces to the west of the Outer Hebrides, Scotland, during the Rockall Haddock Survey (2010), the OFFCON Rockall Survey (2011), the Rockall Anglerfish Survey (2010, 2013 and 2014) and the Deepwater Time Series (2008, 2009 and 2011), and to the North East of Scotland during the North Sea Anglerfish Survey (2012). Further occurrences from similar surveys over the period 2005-2016 are used to improve the known distribution (Fig. 1; Suplementary material Table S1). Overall, these surveys covered a depth range of 42 to $2145 \mathrm{~m}$.

All material analysed from the Scotia cruises was collected using a demersal fish trawl with both the codend and the full body of the net being thoroughly examined for specimens after each deployment. Pennatulaceans of all types, including the new specimens studied here, were rarely recorded in the codend but commonly encountered meshed in the wings or belly 


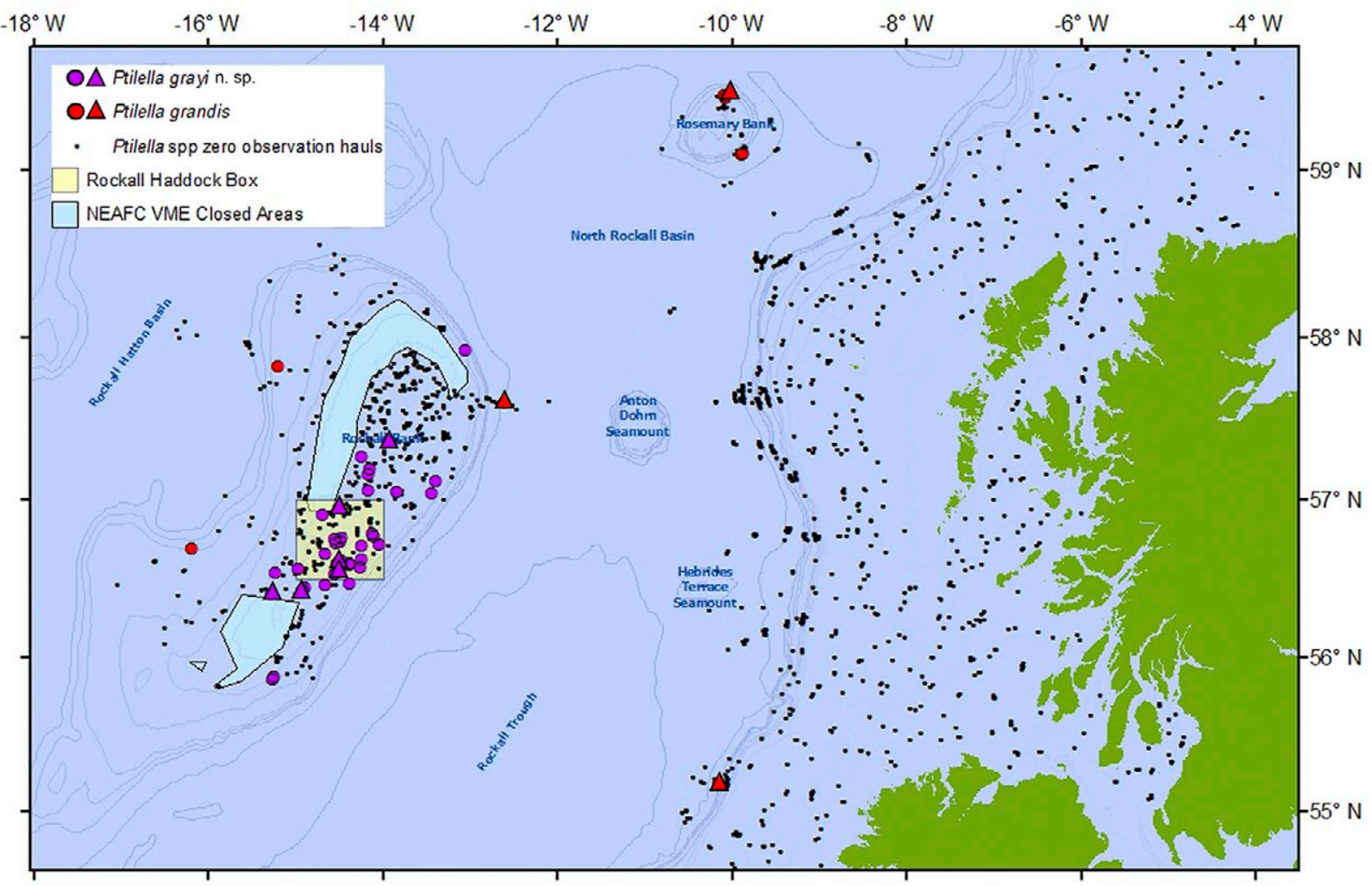

Fig. 1. - Known distribution of Ptilella grayi n. sp. (violet symbols) and Ptilella grandis (red symbols) in the study area and hauls with no occurrences (black dots). Symbols represent approximate midpoints of hauls. Circles indicate sampling stations where the species was recorded only, while triangles indicate sampling stations where the species was both recorded and examined over the course of this study. Map (C) Crown copyright.

of the trawl. Observations from a total of 1541 trawl deployments were used to provide distributional data on the genus. Temperature data close to the seabed were recorded using either a vertical deployment of the Seabird 19+ CTD profiler or a Star-Oddi DST logger mounted on the headline of the net. Both gave temperatures of the water within 3 to $5 \mathrm{~m}$ of the seabed. The relevant information on materials and sampling stations of these and other comparative material used in this paper is compiled in Table 1.

Pennatulacean colonies were sorted, labelled and fixed in buffered formalin (5\% in seawater). After the fixation period, colonies were preserved in $70 \%$ ethanol. A certain number of colonies were directly fixed in $100 \%$ ethanol for further molecular studies.

For comparative purposes, the morphology of additional Pennatula species was also examined. These colonies were collected during various benthic surveys and over different geographical areas: Antarctica (BIOROSS), the northeastern Atlantic-Arctic (BIOICE), the northeastern Atlantic (Scotia cruises, INDEMARES Chica), the southeastern Atlantic (BENGUELA VIII), and the Mediterranean (INDEMARES Alborán). A subsample of these were sequenced (Table 2).

The material from the Scotia cruises referred to here is deposited in the National Museum of Scotland (NMS), in the Natural History Museum in London (NHM), in the Museu de Zoologia de Barcelona (MZB) and in the collection of the research group Biodiversidad y Ecología Acuática of the University of Seville (BECA).

\section{External morphology and SEM study}

Sclerites of different parts of the colonies were prepared for SEM study employing the standard methodology described by several authors (e.g. Bayer and Stefani 1988), and permanent mounts were made for examination using light microscopy. Sclerite dimensions and illustrations are based on the holotype or indicated lot. Colony and sclerite terminology follows Bayer et al. (1983).

\section{DNA extraction, PCR amplification and sequencing}

Total genomic DNA was extracted from ethanol $(\mathrm{EtOH})$-preserved specimens using the EZNA DNA kit (OmegaBiotech), following the manufacturer's instructions. Two mitochondrial regions, mtMutS (=msh1) and Coxl, plus a nuclear region, $28 S$ ribosomal DNA, were sequenced. These three markers are concatenated as this has been considered an octocoral barcode (McFadden et al. 2014). The start of the mtMutS region was amplified using the primers ND42599F and MUT3458R (France and Hoover 2002, Sánchez et al. 2003). The Coxl region was amplified using the primers COII8068F and COIOCTR (France and Hoover 2002, McFadden et al. 2004). The $28 S$ nuclear ribosomal gene (28S rDNA) was amplified using the primers 28S-Far and 28S-Rar (McFadden and van Ofwegen 2013). Each PCR used 0.5 U of DNA Stream Polymerase (BIORON), $0.2 \mathrm{mM}$ 
Table 1. - Sampling data associated with the Atlantic material of Ptilella compared in this paper. Abbreviations: NMS, National Museum of Scotland; MZB, Museu de Zoologia de Barcelona; NHM, Natural History Museum in London; BECA, Biodiversidad y Ecología Acuática of the University of Seville; n.a., not available; i.c., incomplete colony.

\begin{tabular}{|c|c|c|c|c|c|c|c|c|}
\hline Species & Status & Registration code & Cruise & $\begin{array}{l}\text { Cruise } \\
\text { no. } \\
\text { (haul) }\end{array}$ & $\begin{array}{l}\text { Area and coordinates } \\
\text { Start - Stop }\end{array}$ & $\begin{array}{l}\text { Dept } \\
\text { range }(\mathrm{m})\end{array}$ & Date & $\begin{array}{l}\mathrm{N}^{\mathrm{o}} \text { colonies } \\
\text { (total length; } \\
\mathrm{mm} \text { ) }\end{array}$ \\
\hline Ptilella grayi $\mathrm{n} . \mathrm{sp}$. & Holotype & NMS.Z.2019.2.1 & $\begin{array}{c}\text { Rockall } \\
\text { Haddock } \\
\text { Survey } 2011\end{array}$ & $\begin{array}{c}1011 \mathrm{~S} \\
(\mathrm{~S} 11426)\end{array}$ & $\begin{array}{c}\text { Rockall Bank, NE Atlantic } \\
56^{\circ} 32.63^{\prime} \mathrm{N} 14^{\circ} 30.92^{\prime} \mathrm{W} \\
56^{\circ} 33.97^{\prime} \mathrm{N} 14^{\circ} 28.78^{\prime} \mathrm{W}\end{array}$ & $198-202$ & 30 Aug 2011 & $1(474)$ \\
\hline Ptilella grayi $\mathrm{n} . \mathrm{sp}$ & Paratype & NMS.Z.2019.2.2 & $\begin{array}{c}\text { Rockall } \\
\text { Anglerfish } \\
\text { Survey } 2010\end{array}$ & $\begin{array}{c}0410 \mathrm{~S} \\
(\mathrm{~S} 10150)\end{array}$ & $\begin{array}{c}\text { Rockall Bank, NE Atlantic } \\
56^{\circ} 25.22^{\prime} \mathrm{N} 15^{\circ} 14.67^{\prime} \mathrm{W} \\
56^{\circ} 22.91^{\prime} \mathrm{N} 15^{\circ} 18.75^{\prime} \mathrm{W}\end{array}$ & $246-261$ & 6 Apr 2010 & $1(254)$ \\
\hline Ptilella grayi $\mathrm{n} . \mathrm{sp}$ & Paratype & NMS.Z.2019.2.3 & $\begin{array}{c}\text { Rockall } \\
\text { Haddock } \\
\text { Survey } 2011\end{array}$ & $\begin{array}{c}1011 S \\
(\mathrm{~S} 11426)\end{array}$ & $\begin{array}{c}\text { Rockall Bank, NE Atlantic } \\
56^{\circ} 32.63^{\prime} \mathrm{N} 14^{\circ} 30.92^{\prime} \mathrm{W} \\
56^{\circ} 33.97^{\prime} \mathrm{N} 14^{\circ} 28.78^{\prime} \mathrm{W}\end{array}$ & $198-202$ & 30 Aug 2011 & $1(471)$ \\
\hline Ptilella grayi $\mathrm{n} . \mathrm{sp}$ & Paratype & MZB 2018-0761 & $\begin{array}{c}\text { Rockall } \\
\text { Haddock } \\
\text { Survey } 2011\end{array}$ & $\begin{array}{c}1011 \mathrm{~S} \\
(\mathrm{~S} 11426)\end{array}$ & $\begin{array}{c}\text { Rockall Bank, NE Atlantic } \\
56^{\circ} 32.63^{\prime} \mathrm{N} 14^{\circ} 30.92^{\prime} \mathrm{W} \\
56^{\circ} 33.97^{\prime} \mathrm{N} 14^{\circ} 28.78^{\prime} \mathrm{W}\end{array}$ & $198-202$ & 30 Aug 2011 & $1(391)$ \\
\hline Ptilella grayi $\mathrm{n} . \mathrm{sp}$ & & NMS.Z.2019.2.4 & $\begin{array}{l}\text { OFFCON } \\
2012\end{array}$ & $\begin{array}{c}0712 \mathrm{~S} \\
(\mathrm{~S} 12287)\end{array}$ & $\begin{array}{c}\text { Rockall Bank, NE Atlantic } \\
57^{\circ} 22.33^{\prime} \mathrm{N} 13^{\circ} 54.87^{\prime} \mathrm{W} \\
57^{\circ} 21.36^{\prime} \mathrm{N} 13^{\circ} 57.73^{\prime} \mathrm{W}\end{array}$ & $146-152$ & 24 Jul 2012 & $1(305)$ \\
\hline Ptilella grayi $\mathrm{n} . \mathrm{sp}$ & & NMS.Z.2019.2.5 & $\begin{array}{c}\text { Rockall } \\
\text { Anglerfish } \\
\text { Survey } 2013\end{array}$ & $\begin{array}{c}1413 \mathrm{~S} \\
(\mathrm{~S} 13371)\end{array}$ & $\begin{array}{c}\text { Rockall Bank, NE Atlantic } \\
56^{\circ} 36.59^{\prime} \mathrm{N} 14^{\circ} 26.65^{\prime} \mathrm{W} \\
56^{\circ} 35.81^{\prime} \mathrm{N} 14^{\circ} 32.89^{\prime} \mathrm{W}\end{array}$ & 197-199 & 24 Oct 2013 & $1(450)$ \\
\hline Ptilella grayi n. sp & & MZB 2018-0762 & $\begin{array}{c}\text { Rockall } \\
\text { Anglerfish } \\
\text { Survey } 2013\end{array}$ & $\begin{array}{c}1413 \mathrm{~S} \\
(\mathrm{~S} 13372)\end{array}$ & $\begin{array}{c}\text { Rockall Bank, NE Atlantic } \\
56^{\circ} 55.42^{\prime} \mathrm{N} 14^{\circ} 31.33^{\prime} \mathrm{W} \\
56^{\circ} 58.65^{\prime} \mathrm{N} 14^{\circ} 28.61^{\prime} \mathrm{W}\end{array}$ & $179-188$ & 24 Oct 2013 & $1(450)$ \\
\hline Ptilella grayi $\mathrm{n} . \mathrm{sp}$ & & BECA OPEN-335 & $\begin{array}{c}\text { Rockall } \\
\text { Anglerfish } \\
\text { Survey } 2013\end{array}$ & $\begin{array}{c}1413 \mathrm{~S} \\
(\mathrm{~S} 13371)\end{array}$ & $\begin{array}{c}\text { Rockall Bank, NE Atlantic } \\
56^{\circ} 36.59^{\prime} \mathrm{N} 14^{\circ} 26.65^{\prime} \mathrm{W} \\
56^{\circ} 35.81^{\prime} \mathrm{N} 14^{\circ} 32.89^{\prime} \mathrm{W}\end{array}$ & $197-199$ & 24 Oct 2013 & $1(575)$ \\
\hline Ptilella grayi $\mathrm{n} . \mathrm{sp}$ & & NHMUK 2019.1 & $\begin{array}{c}\text { Rockall } \\
\text { Anglerfish } \\
\text { Survey } 2013\end{array}$ & $\begin{array}{c}1413 \mathrm{~S} \\
(\mathrm{~S} 13371)\end{array}$ & $\begin{array}{c}\text { Rockall Bank, NE Atlantic } \\
56^{\circ} 36.59^{\prime} \mathrm{N} 14^{\circ} 26.65^{\prime} \mathrm{W} \\
56^{\circ} 35.81^{\prime} \mathrm{N} 14^{\circ} 32.89^{\prime} \mathrm{W}\end{array}$ & 197-199 & 24 Oct 2013 & $1(570)$ \\
\hline Ptilella grayi $\mathrm{n} . \mathrm{sp}$ & & MZB 2018-0763 & $\begin{array}{c}\text { Rockall } \\
\text { Anglerfish } \\
\text { Survey } 2013\end{array}$ & $\begin{array}{c}1413 \mathrm{~S} \\
(\mathrm{~S} 13371)\end{array}$ & $\begin{array}{c}\text { Rockall Bank, NE Atlantic } \\
56^{\circ} 36.59^{\prime} \mathrm{N} 14^{\circ} 26.65^{\prime} \mathrm{W} \\
56^{\circ} 35.81^{\prime} \mathrm{N} 14^{\circ} 32.89^{\prime} \mathrm{W}\end{array}$ & 197-199 & 24 Oct 2013 & $1(545)$ \\
\hline Ptilella grayi $\mathrm{n} . \mathrm{sp}$ & & BECA OPEN-338 & $\begin{array}{c}\text { Rockall } \\
\text { Anglerfish } \\
\text { Survey } 2013\end{array}$ & $\begin{array}{c}1413 \mathrm{~S} \\
(\mathrm{~S} 13371)\end{array}$ & $\begin{array}{c}\text { Rockall Bank, NE Atlantic } \\
56^{\circ} 36.59^{\prime} \mathrm{N} 14^{\circ} 26.65^{\prime} \mathrm{W} \\
56^{\circ} 35.81^{\prime} \mathrm{N} 14^{\circ} 32.89^{\prime} \mathrm{W}\end{array}$ & 197-199 & 24 Oct 2013 & $1(572)$ \\
\hline Ptilella grayi $\mathrm{n} . \mathrm{sp}$ & & BECA OPEN-339 & $\begin{array}{c}\text { Rockall } \\
\text { Anglerfish } \\
\text { Survey } 2014\end{array}$ & $\begin{array}{c}0414 \mathrm{~S} \\
(\mathrm{~S} 14141)\end{array}$ & $\begin{array}{c}\text { Rockall Bank, NE Atlantic } \\
56^{\circ} 25.40^{\prime} \mathrm{N} 14^{\circ} 57.37^{\prime} \mathrm{W} \\
56^{\circ} 26.56^{\prime} \mathrm{N} 14^{\circ} 54.75^{\prime} \mathrm{W}\end{array}$ & $206-215$ & 14 Apr 2014 & +1 i.c. (115) \\
\hline Ptilella grayi $\mathrm{n} . \mathrm{sp}$ & & BECA OPEN-340 & $\begin{array}{c}\text { Rockall } \\
\text { Anglerfish } \\
\text { Survey } 2014\end{array}$ & $\begin{array}{c}0414 \mathrm{~S} \\
(\mathrm{~S} 14141)\end{array}$ & $\begin{array}{c}\text { Rockall Bank, NE Atlantic } \\
56^{\circ} 25.40^{\prime} \mathrm{N} 14^{\circ} 57.37^{\prime} \mathrm{W} \\
56^{\circ} 26.56^{\prime} \mathrm{N} 14^{\circ} 54.75^{\prime} \mathrm{W}\end{array}$ & $206-215$ & 14 Apr 2014 & $t 1$ i.c. $(90)$ \\
\hline $\begin{array}{l}\text { Ptilella grandis } \\
\text { (Ehrenberg, 1834) }\end{array}$ & & NMS.Z.2019.2.6 & $\begin{array}{l}\text { Deepwater } \\
\text { Time Series } \\
2008\end{array}$ & $\begin{array}{c}1108 \mathrm{~S} \\
(\mathrm{~S} 08385)\end{array}$ & $\begin{array}{c}\text { Hebridean Slope, NE Atlantic } \\
55^{\circ} 13.79^{\prime} \mathrm{N} 10^{\circ} 08.87^{\prime} \mathrm{W} \\
55^{\circ} 08.49^{\prime} \mathrm{N} 10^{\circ} 10.66^{\prime} \mathrm{W}\end{array}$ & $\begin{array}{l}1018- \\
1078\end{array}$ & 14 Sept 2008 & $1(256)$ \\
\hline $\begin{array}{l}\text { Ptilella grandis } \\
\text { (Ehrenberg, 1834) }\end{array}$ & & MZB 2018-0759 & $\begin{array}{l}\text { OFFCON } \\
2011\end{array}$ & $\begin{array}{c}0711 S \\
(\mathrm{~S} 11264)\end{array}$ & $\begin{array}{l}\text { NE Rockall, NE Atlantic } \\
57^{\circ} 36.37^{`} \mathrm{~N} 12^{\circ} 36.66^{\circ} \mathrm{W} \\
57^{\circ} 35.94^{\circ} \mathrm{N} 12^{\circ} 36.98^{\circ} \mathrm{W}\end{array}$ & $\begin{array}{l}1601- \\
1605\end{array}$ & 30 Jun 2011 & $1(182)$ \\
\hline $\begin{array}{l}\text { Ptilella grandis } \\
\text { (Ehrenberg, 1834) }\end{array}$ & & NHMUK 2019. 2 & $\begin{array}{l}\text { North Sea } \\
\text { Anglerfish } \\
\text { Survey } 2012\end{array}$ & $\begin{array}{c}0412 \mathrm{~S} \\
(\mathrm{~S} 12220)\end{array}$ & $\begin{array}{l}\text { S Norwegian Sea, NE Atlantic } \\
61^{\circ} 55.05^{\prime} \mathrm{N} 02^{\circ} 28.94^{\prime} \mathrm{E} \\
61^{\circ} 52.66^{\prime} \mathrm{N} 02^{\circ} 34.22^{\prime} \mathrm{E}\end{array}$ & $390-396$ & 29 Apr 2012 & $1(510)$ \\
\hline $\begin{array}{l}\text { Ptilella grandis } \\
\text { (Ehrenberg, 1834) }\end{array}$ & & BECA OPEN-143 & BIOICE & $\begin{array}{c}516 \\
(3507)\end{array}$ & $\begin{array}{c}\text { South Iceland, NE Atlantic } \\
61^{\circ} 54.95^{\prime} \mathrm{N}, 19^{\circ} 17.02^{\prime} \mathrm{W}\end{array}$ & 1595 & 3 Sept 2002 & $1(114)$ \\
\hline $\begin{array}{l}\text { Ptilella inflata } \\
\text { (Kükenthal, 1910) }\end{array}$ & & NMS.Z.2019.2.7 & Benguela VIII & 67 & $\begin{array}{l}\text { Namibia, SE Atlantic } \\
23^{\circ} 28.03^{\prime} \text { S } 13^{\circ} 05.08^{\prime} \mathrm{E}\end{array}$ & 418 & 23 Jul 1985 & $1(203)$ \\
\hline $\begin{array}{l}\text { Ptilella inflata } \\
\text { (Kükenthal, 1910) }\end{array}$ & & NHMUK 2019. 3 & Benguela VIII & 67 & $\begin{array}{l}\text { Namibia, SE Atlantic } \\
23^{\circ} 28.03^{\prime} \mathrm{S} 13^{\circ} 05.08^{\prime} \mathrm{E}\end{array}$ & 418 & 23 Jul 1985 & $1(207)$ \\
\hline $\begin{array}{l}\text { Ptilella inflata } \\
\text { (Kükenthal, 1910) }\end{array}$ & & MZB 2018-0760: & Benguela VIII & 67 & $\begin{array}{c}\text { Namibia, SE Atlantic } \\
23^{\circ} 28.03^{\prime} \mathrm{S} 13^{\circ} 05.08^{\prime} \mathrm{E}\end{array}$ & 418 & 23 Jul 1985 & $1(227)$ \\
\hline $\begin{array}{l}\text { Ptilella bellissima } \\
\text { (Fowler, 1888) }\end{array}$ & Holotype & $\begin{array}{c}\text { BMNH } \\
(1888.6 .28 .1)\end{array}$ & n.a. & n.a. & $\begin{array}{c}\text { Bahamas Islands, } \\
\text { NW Atlantic }\end{array}$ & n.a. & 14 Feb 1888 & $1(178)$ \\
\hline
\end{tabular}

of dNTPs, $0.3 \mu \mathrm{M}$ of each primer and approximately $30 \mathrm{ng}$ of genomic DNA, and was brought to a final volume of $25 \mu \mathrm{L}$ with $\mathrm{H}_{2} \mathrm{O}$. The mtMutS PCR was carried out using the following cycle profile: initial denaturation at $94^{\circ} \mathrm{C}$ for $2 \mathrm{~min}, 35$ cycles of dena- turation at $94^{\circ} \mathrm{C}$ for $30 \mathrm{~s}$, annealing at $55^{\circ} \mathrm{C}$ for $30 \mathrm{~s}$, extension at $72^{\circ} \mathrm{C}$ for $30 \mathrm{~s}$, and a final extension at $72^{\circ} \mathrm{C}$ for 5 min. The Coxl PCR used the same cycle profile with $58^{\circ} \mathrm{C}$ as the annealing temperature and 40 s for extension duration on each of the 35 cycles. The 
Table 2. - Pennatulaceans included in the molecular phylogenetic analyses. Species in bold are those sequenced for this study. Note that all GenBank sequences are presented here with the names as they appear in GenBank and their original publications.

\begin{tabular}{|c|c|c|c|c|c|}
\hline Family / Species & $\begin{array}{l}\text { Catalog numbers } \\
\text { (or additional information) }\end{array}$ & Geographic area & $m t M u t S(=m s h 1)$ & $\operatorname{Cox} 1$ & $28 S$ \\
\hline \multicolumn{6}{|l|}{ Pennatulidae } \\
\hline Ptilella grandis & BECA OPEN-143 & South Iceland, NE Atlantic & МК603844 & MK603860 & МK603854 \\
\hline Ptilella grandis & NMS.Z.2019.2.6 & Hebridean Slope, NE Atlantic & MK603843 & MK882496 & MK882494 \\
\hline Ptilella grayi n. sp. (Holotype) & NMS.Z.2019.2.1 & Rockall Bank, NE Atlantic & МК603847 & MK882497 & MK882495 \\
\hline Ptilella grayi n. sp. (Paratype) & NMS.Z.2019.2.2 & Rockall Bank, NE Atlantic & МK603846 & MK603856 & MK603853 \\
\hline Pennatula rubra & BECA OPEN-139 & Alborán, Mediterranean Sea & MK603845 & MK603857 & MK603852 \\
\hline Pennatula phosphorea & BECA OPEN-453 & Sea of the Hebrides, NE Atlantic & MK603848 & MK603858 & MK882492 \\
\hline Pennatula phosphorea & BECA OPEN-454 & Gulf of Cádiz, NE Atlantic & MK603850 & MK603861 & MK882491 \\
\hline Pennatula sp. & BECA OPEN-152 & Ross Sea, Antarctica & МK603849 & MK603859 & MK882493 \\
\hline Pennatula phosphorea* & MBARI K2-06-070110-01 & USA, Eastern Pacific & KX904975 & KX9049575 & \\
\hline Pennatula phosphorea* & NWFSC 34212-045 & USA, Eastern Pacific & JN8665312 & KF8741902 & \\
\hline Ptilosarcus gurneyi & NWFSC 34212-082 & USA, Eastern Pacific & JN866536 2 & KF874195 2 & \\
\hline Ptilosarcus gurneyi & NWFSC 34213-020 & USA, Eastern Pacific & JN866540² & KF8742012 & \\
\hline \multicolumn{6}{|l|}{ Virgularidae } \\
\hline Acanthoptilum gracile & NWFSC 34210-026 & USA, Eastern Pacific & JN8665252 & KF874184² & \\
\hline Acanthoptilum gracile & NWFSC 34212-029 & USA, Eastern Pacific & JN8665292 & KF874188 2 & \\
\hline \multicolumn{6}{|l|}{ Echinoptilidae } \\
\hline Actinoptilum molle & RMNH Coel.40822 & n.d. & GQ34249133 & GQ342414³ & JX203738 \\
\hline \multicolumn{6}{|l|}{ Protoptilidae } \\
\hline Distichoptilum gracile & NTM C14561 & AUS, Tasman Sea, & DQ302866 & GQ34245433 & JX2037394 \\
\hline Stachyptilidae & & & & & \\
\hline Gilibelemnon octodentatum & BECA OPEN-452 & Seymour Island, Antarctica & MK603841 & MK603855 & MK603851 \\
\hline \multicolumn{6}{|l|}{ Renillidae } \\
\hline Renilla muelleri & SCF-FLA & USA, Gulf of Mexico & DQ2974321 & NC_018378 1 & \\
\hline Renilla sp. & UF4000 & Off California coast, Pacific & GQ3425263 & GQ3424553 & \\
\hline \multicolumn{6}{|l|}{ Outgroup (Ellisellidae) } \\
\hline Viminella sp. & RMNH Coel.40032 & n.d. & JX2037944 & JX2038524 & JX2037034 \\
\hline Viminella $\mathrm{sp}$. & RMNH Coel.40813 & n.d. & GQ342493³ & GQ342416 3 & JX2037054 \\
\hline
\end{tabular}

Abbreviations: NMS, National Museum Scotland; NHM, Natural History Museum (London, UK); MZB, Museu de Zoologia de Barcelona (Spain); BECA, Biodiversidad y Ecología Acuatica (Seville, Spain); MBARI, Monterey Bay Aquarium Research Institute (California, U.S.A.); NWFSC, Northwest Fisheries Science Center (Seattle, U.S.A.); NIWA, National Institute of Water and Atmospheric Research (Auckland, New Zealand); NOCS, National Oceanography Centre (Southampton, UK), RMNH, Rijksmuseum van Natuurlijke Historie (Leiden, Netherlands); NTM, Museum and Art Gallery of the Northern Territory (Darwin city, Australia); SCF, Collection of S.C. France (U.S.A.); UF, Florida Natural History Museum (Florida; U.S.A.). n.d.: no data.*: Both specimens are from the North Eastern Pacific. However, despite these specimens being originally identified as Pennatula phosphorea, according to the phylogenetic hypothesis presented in this paper (see Fig. 5) we consider these identifications as doubtful. We suggest these findings as indicative of a morphospecies and thus deserving of further research.

References: ( $\left.{ }^{1}\right)$ McFadden et al. 2006; ( $\left.{ }^{2}\right)$ Elz et al. unpublished; ( $\left.{ }^{3}\right)$ Brockman and McFadden 2012; $\left({ }^{4}\right)$ McFadden and van Ofwegen 2012; $\left({ }^{5}\right)$ Everett et al. 2016.

28S PCR used the same cycle as the Coxl profile, but with $50^{\circ} \mathrm{C}$ as the annealing temperature. PCR products were purified using the NucleoSpin ${ }^{\circledR}$ Extract II DNA Purification Kit, following the manufacturer's instructions. Purified products were electrophoresed on an ABI PRISM® 3730xl genetic analyser, and sequence traces were edited using Sequencher ${ }^{\mathrm{TM}}$ v4.0.

According to the molecular phylogeny of Dolan et al. (2013) and Kushida and Reimer (2018), Pennatula species were included in Clade II. As no clear basal relationships have been demonstrated among the three pennatulacean clades, for the present study sequences of two ellisellids from GenBank were selected as outgroups. The set of new sequences obtained in this study and those from GenBank (see Table 2) were aligned using MUSCLE and then implemented in MEGA5 (Tamura et al. 2011). After alignment, the best nucleotide substitution model was selected using Modeltest implemented in MEGA 5 according to Akaike Information Criterion and hierarchical likelihood ratio test (hLRT) values. The phylogenetic reconstruction was obtained by applying maximum likelihood and Bayesian inference methods. The maximum likelihood method was carried out in MEGA 5 using the nearest neighbour interchange heuristic method and 1000 bootstrap replications. The selected nucleotide substitution model was
T92+G+I for the concatenated mtMutS+Cox $1+28 S$ data set. The Bayesian inference was carried out with MrBayes v3.1.2 (Huelsenbeck and Ronquist 2001, Ronquist and Huelsenbeck 2003), using the substitution model GTR $+\mathrm{G}$ (lset nst $=6$ rates $=$ gamma) and $10^{7}$ generations, and discarding $25 \%$ of the initial trees.

\section{RESULTS}

\author{
Subclass OCTOCORALLIA Haeckel, 1866 \\ Order Pennatulacea Verrill, 1865 \\ Family Pennatulidae Ehrenberg, 1834 \\ Genus Ptilella Gray, 1870
}

Ptilella Gray 1870: 21; Koren and Danielssen 1874: 422, 1877: 82. Pennatula, Kölliker 1872: 136 (in part); Kölliker 1880: 4 (in part); Grieg 1892: 10 (in part); Jungersen 1904: 11 (in part); Kükenthal and Broch 1910: 348 (in part); Broch 1913: 28 (in part); Kükenthal 1915: 81 (in part); Hickson 1916: 181 (in part), 1937: 123; Williams 1995a: 125 (in part); López-González et al. 2001: 70 (in part); Altuna 2015: 2 (in part). Pennatula (Ptilella), Verrill 1883: 3, 1885: 532 (in part).

Diagnosis (modified from Gray 1870: 21). Colonies pinnate. Rachis bilaterally symmetrical throughout. Rachis with a central dorsal track naked of zooids. Rachispeduncle limit with a distinct thickening or swelling, the thickening sometimes forming an edged ring at the 
thickest point. Axis circular in section, present throughout the entire colony. Polyp leaves large, conspicuous and fan-shaped. Autozooids in groups of 3-4 (occasionally 2) polyps on ventral edge of polyp leaves, groups of polyps in oblique lines. Anthocodiae retractile into spiculiferous, tubular and eight-toothed calyces. Siphonozooids numerous, on the axillae of polyp leaves. Mesozooids on rachis (on both sides of longitudinal naked dorsal track) and on the proximal 2/3 part of dorsal edge of polyp leaves. Dorsal edge of polyp leaves without zooids distally. Sclerites three-flanged and rods. Sclerites at the upper and lower parts of rachis-peduncle limit distinctly differentiated (three-flanged spindles in upper portion, but smaller rods in lower portion).

Type species. Pennatula borealis Sars, 1846 (=Pennatula grandis Ehrenberg, 1834), by monotypy.

Remarks. Four Atlantic species are here attributed to this genus: Ptilella grandis (Ehrenberg, 1834) comb. nov. (N Atlantic), Ptilella bellissima (Fowler, 1888), (NE Atlantic), Ptilella inflata (Kükenthal, 1910) n. comb. (W Indian and SE Atlantic), and Ptilella grayi n. sp. (NE Atlantic). Furthermore, the morphological descriptions of another four Pacific species, $P$. naresi Kölliker (1880: 2), P. pearceyi Kölliker (1880: 4), $P$. murrayi Kölliker (1880: 5), and P. moseleyi Kölliker (1880: 6), suggest that these could also belong to the genus Ptilella. They are here tentatively included in Ptilella, although revised and updated morphological and molecular information is necessary to establish this conclusively (see also Discussion). The molecular analysis carried out in this paper suggests the need for a re-evaluation of the previously considered morphological variability within the genus Pennatula. Our study reveals that an historical attempt to segregate some of these characters had already been undertaken by Gray (1870) in describing the genus Ptilella. As this is in concordance with our molecular data, Ptilella is resurrected here.

\section{Ptilella grayi n. sp.}

(Figs 1-3)

http://zoobank.org/9844EDA5-AAEC-4884-A054-6CBDE378BE15

Holotype: NMS.Z.2019.2.1, Rockall Haddock Survey cruise 1011S (haul S11426), $56^{\circ} 32.63 \mathrm{~N} 14^{\circ} 30.92 \mathrm{~W}$ to $56^{\circ} 33.97 \mathrm{~N} 14^{\circ} 28.78 \mathrm{~W}$, northeastern Atlantic, 198-202 m depth, 30 Aug 2011.

Paratypes: NMS.Z.2019.2.2, Rockall Anglerfish Survey 2010 cruise 0410S (haul S10150), $56^{\circ} 25.22 \mathrm{~N} 15^{\circ} 14.67 \mathrm{~W}$ to $56^{\circ} 22.91 \mathrm{~N}$ $15^{\circ} 18.75 \mathrm{~W}$, northeastern Atlantic, 246-261 m depth, 6 Apr 2010. NMS.Z.2019.2.3, Rockall Haddock Survey cruise 1011S (haul $\mathrm{S} 11426$ ), $56^{\circ} 25.22 \mathrm{~N} 15^{\circ} 14.67 \mathrm{~W}$ to $56^{\circ} 22.91 \mathrm{~N} 15^{\circ} 18.75 \mathrm{~W}$, northeastern Atlantic, 198-202 m depth, 30 Aug 2011. MZB 2018-0761, Rockall Haddock Survey cruise 1011S (haul S11426), 56²5.22N $15^{\circ} 14.67 \mathrm{~W}$ to $56^{\circ} 22.91 \mathrm{~N} 15^{\circ} 18.75 \mathrm{~W}$, northeastern Atlantic, 198$202 \mathrm{~m}$ depth, 30 Aug 2011.

See Table 1 for additional materials.

Description of the holotype. Colony elongate, pinnate, and erect (Fig. 2A), $457 \mathrm{~mm}$ in length in preserved state. Axis present throughout colony, rounded in cross section, $5 \mathrm{~mm}$ in maximum diameter. Rachis bilaterally
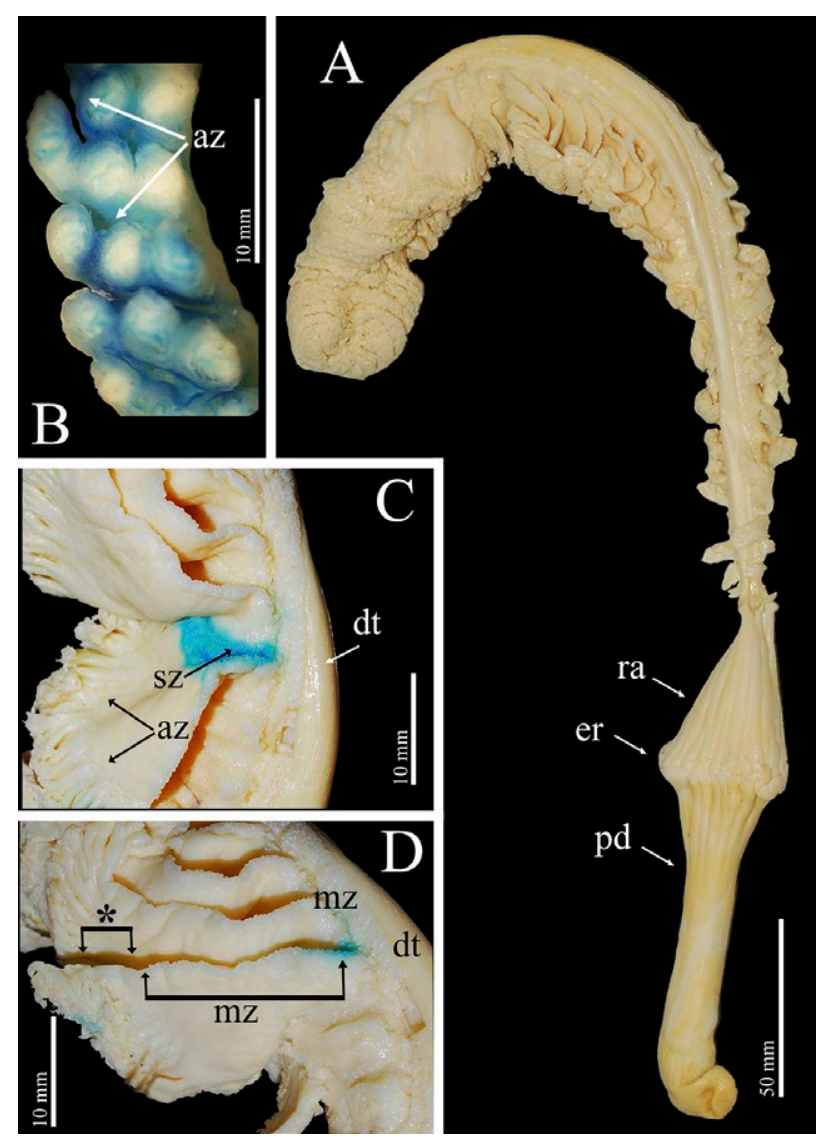

Fig. 2. - Ptilella grayi n. sp. Holotype (NMS.Z.2019.2.1). A, whole colony, showing the edged ring (er) betwen peduncle (pd) and rachis (re); B, detail of autozooids (az) in oblique rows, sectioned basally; $\mathrm{C}$, dorsal view of polyp leaves showing the location of mesozooids (mz), siphonozooids (sz) and the distal part devoid of polyps (asterisk); D, area between two polyp leaves from latero-dorsal view showing the location of siphonozooids (sz), autozooids (az) on the ventral edge of the polyp-leaf, and the naked dorsal track (dt). Note that some parts in B to D are stained with methylene blue for increasing contrast.

symmetrical, $354 \mathrm{~mm}$ in length (77\% of overall length) and $42 \mathrm{~mm}$ in width, with a distinctive naked dorsal and ventral track visible along the rachis. Rachis-peduncle limit with a prominent edged ring (Fig. 2A: er). Peduncle $103 \mathrm{~mm}$ in length (23\% of overall length) and 36 $\mathrm{mm}$ in width at the widest point (the thickening). Rachis with 94 polyp leaves, inserted obliquely and extending ventrally upward, leaves gradually increasing in size along the rachis until the mid-zone, then decreasing in size towards the distal part. Autozooids numerous (approximately 50-60 per polyp-leaf), well developed (up to $5 \mathrm{~mm}$ in length, up to $2 \mathrm{~mm}$ in width), arranged in groups of 3-4 (occasionally 2), forming oblique rows along the polyp-leaf edge (Fig. 2B: az). Anthocodiae retractile into permanent spiculiferous calyces. Calyces densely spiculated and distinctly eight-toothed. Siphonozooids minute, about $0.35-0.50 \mathrm{~mm}$ in diameter, numerous, on the axillae of polyp leaves (Fig. 2C: sz). Mesozooids well developed, $0.50-0.75 \mathrm{~mm}$ in diameter, numerous, situated on the latero-dorsal surface of rachis and at the dorsal edge of polyp leaves (Fig. 2D: mz). Dorsal edge of polyp leaf with distinctive zone free of zooids distally (Fig. 2D:*). 


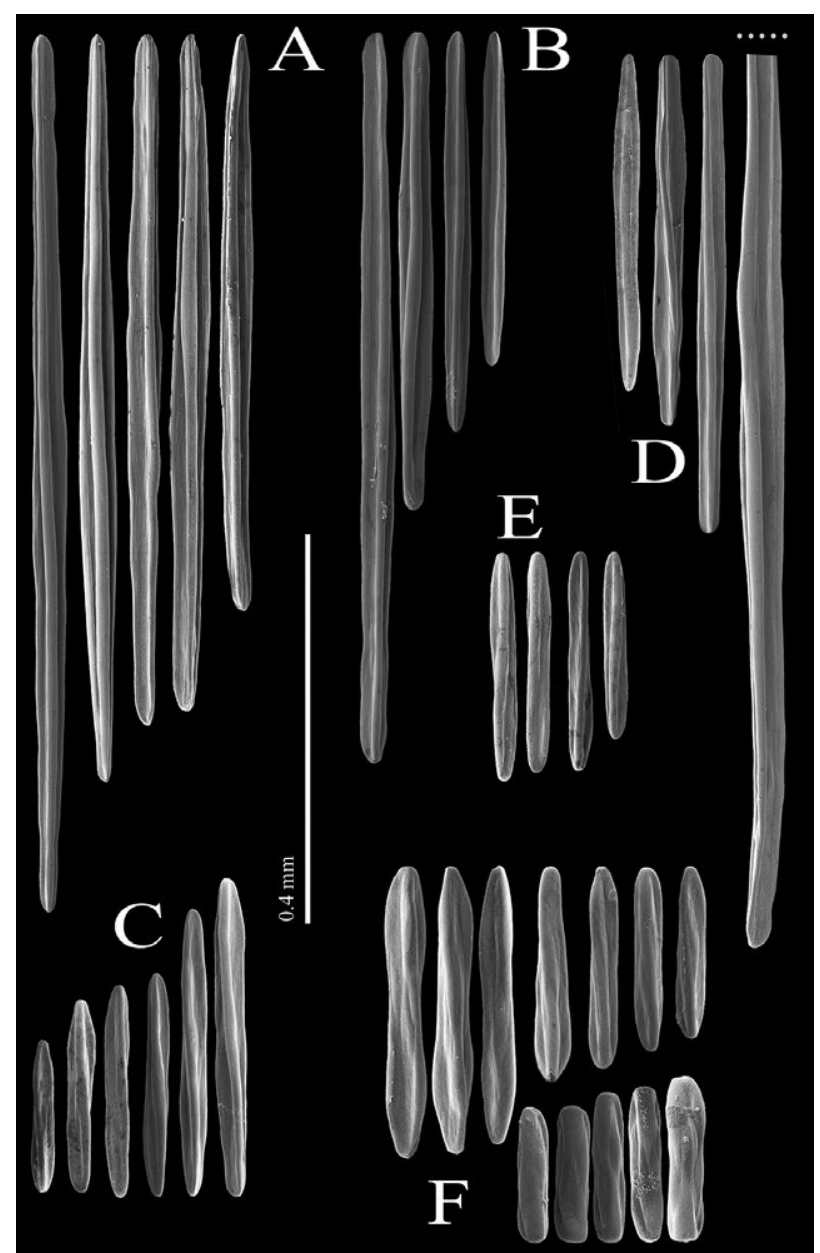

Fig. 3. - Ptilella grayi n. sp. Holotype (NMS.Z.2019.2.1). SEM photographs of sclerites. A, calyces; B, mesozooids; C, siphonozooids; D, polyp leaves; E, dorsal track; F, rachis-peduncle limit, above edged ring (upper row) and below edged ring (lower row).

Sclerites in calyces three-flanged rods, up to 1.20 $\mathrm{mm}$ in length (Fig. 3A). Sclerites absent in walls and tentacles of autozooids. Sclerites of mesozooids threeflanged rods, up to $0.80 \mathrm{~mm}$ in length (Fig. 3B). Sclerites of siphonozooids short, three-flanged rods, up to $0.45 \mathrm{~mm}$ in length (Fig. 3C). Sclerites of polyp-leaf surfaces three-flanged rods, up to $1.45 \mathrm{~mm}$ in length (Fig. 3D). Sclerites in dorsal track scarce, short threeflanged rods, up to $0.40 \mathrm{~mm}$ in length (Fig. 3E). Sclerites above edged ring in conspicuous three-flanged rods, up to $0.30 \mathrm{~mm}$ in length (Fig. 3F, upper row). Sclerites below edged ring short rods, up to $0.18 \mathrm{~mm}$ in length (Fig. 3F, lower row).

Variations. Colonies grow to a considerable size, as evidenced by living specimens being encountered up to $581 \mathrm{~mm}$ length and up to $312 \mathrm{~g}$ in weight (weighed wet with excess water blotted off).

The general colonial structure of the paratype colonies and additional material examined is similar to that of the holotype (see Figs S1 and S2). All preserved colonies examined ranged between 254 and $575 \mathrm{~mm}$ in length. Rachis bilaterally symmetrical with 64-98 polyp leaves. Autozooids numerous, arranged in oblique groups of 2-4 along the ventral edge

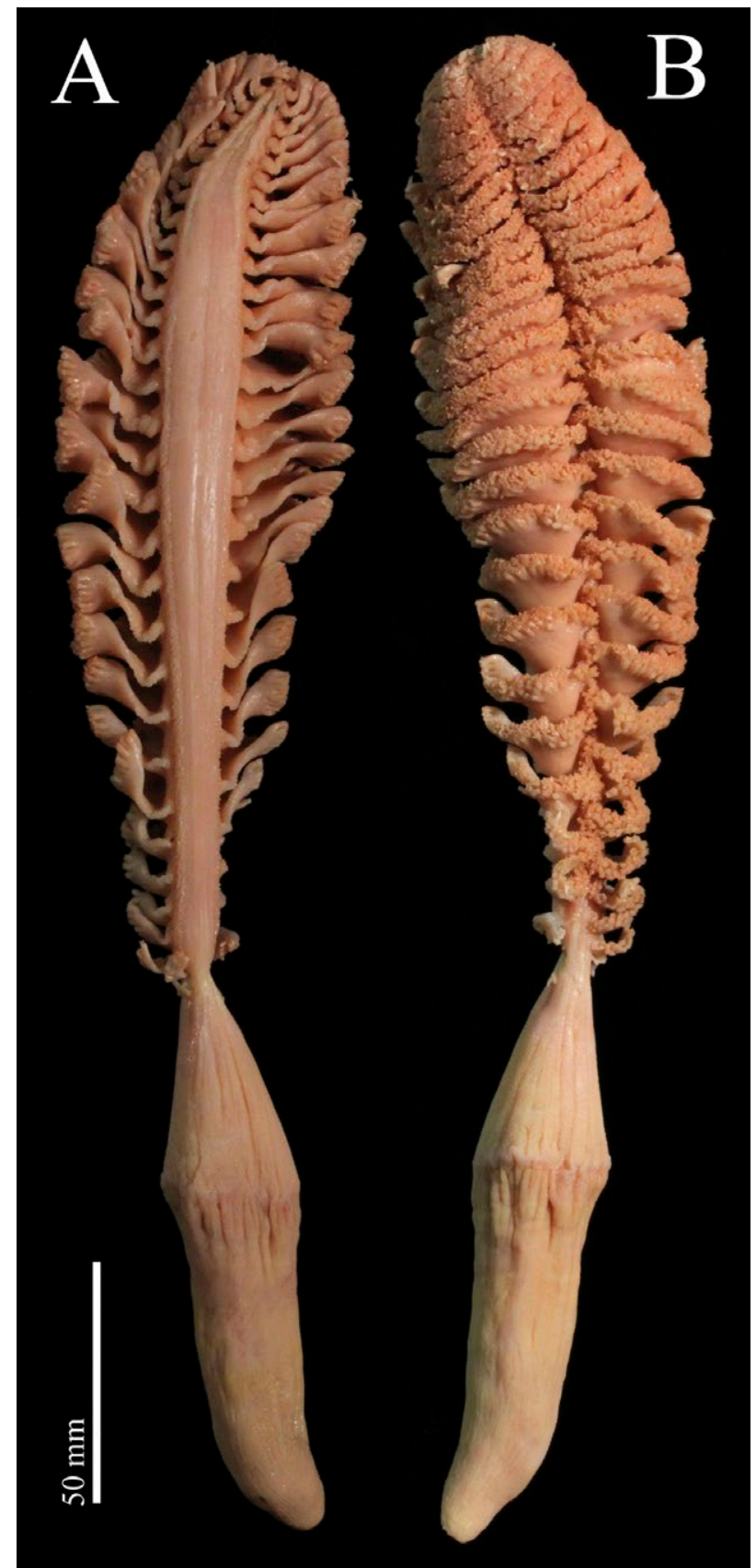

Fig. 4. - Ptilella grayi n. sp. (NMS.Z.2019.2.4). Newly collected specimen, showing a more relaxed rachis-peduncle limit, but still with a distinct edged ring. A, dorsal view; $\mathrm{B}$, ventral view. Both images $(\odot$ Crown copyright.

of polyp leaves, 4.0-6.5 $\mathrm{mm}$ in length and 1.5-2.0 mm in width. Siphonozooids $0.35-0.50 \mathrm{~mm}$ in diameter, on axillar proximal areas of polyp leaves. Mesozooids $0.45-0.75 \mathrm{~mm}$ in diameter, numerous, on two lateral bands flanking a naked dorsal track. Axis rounded in cross section, up to $5.4 \mathrm{~mm}$ in max diameter. Sclerites as in the holotype: those of calyces up to $1.40 \mathrm{~mm}$ in length (Fig. S3A); those of the mesozooids up to 0.80 $\mathrm{mm}$ in length (Fig. S3B); those of the siphonozooids up to $0.50 \mathrm{~mm}$ in length (Fig. S3C); those of the polyp-leaf surfaces up to $1.40 \mathrm{~mm}$ in length (Fig. S3D); those of the dorsal track scarce, up to $0.40 \mathrm{~mm}$ in length (Fig. S3E); those close to the rachis-peduncle 
limit up to $0.35 \mathrm{~mm}$ in length above edged ring (Fig. $\mathrm{S} 3 \mathrm{~F}$, upper row), and up to $0.17 \mathrm{~mm}$ in length below edged ring (Fig. S3F, lower row).

Living colonies range in colour from light yellow/ orange (Fig. 4) through to a delicate salmon pink, the latter having been observed in some small specimens. Preserved examined colonies are a light fleshy to dirty white colour in ethanol. Sclerites are colourless.

Etymology. The name grayi is chosen in honour of Dr. John Edward Gray (1800-1875), in recognition of his contributions to the knowledge of sea pens and of his being the first to recognize and describe Ptilella as a different genus to Pennatula.

Distribution and associated fauna. At present, Ptilella grayi n. sp. is only known from the upper Rockall Bank area (west of the Outer Hebrides in Scotland) from a depth range of 145-389 m (Fig. 1).

The bottom temperature at these localities had a range of $8.40^{\circ} \mathrm{C}$ to $9.73^{\circ} \mathrm{C}$ over the survey period of April to October during the years 2005-2016.

The species is spread over the upper, shallow gradient area of Rockall Bank, but it is broadly centred within the Rockall Haddock Box (RHB) and spreading somewhat towards both the NE and SW. The RHB encloses the entirety of ICES statistical rectangle 42D5 and has been subject to restrictions on mobile commercial fishing since 2001 by agreement between the North East Atlantic Fisheries Commission (NEAFC) and the European Union in order to reduce mortality of stocks of juvenile haddock. To the south and west of the observed distribution of Pt. grayi n. sp. lie two further areas that have been closed by the NEAFC to all forms of commercial fishing: the North-West Rockall Bank, which has been closed since 2007, and the South-West Rockall Area (Empress of Britain Bank), which has been closed since 2013. These closed areas are in place to protect vulnerable marine ecosystems (VME) from anthropogenic degradation, the VME in these cases being aggregations of Lophelia pertusa. Whether the distribution of Pt. grayi n. sp. extends into these areas is, however, presently unknown. Despite an extensive sampling effort, the species has not been recorded in the vicinity of Rockall islet itself. Similarly, Pt. grayi n. sp. has not been recorded at all to date on the upper shelf to the east of the Rockall Trough, despite intensive sampling there over a lengthy timeframe (2010-2017 for the upper shelf and 2005-2016 for the shelf slope) and a wide depth range (42-2147 $\mathrm{m})$.

The area of Pt. grayi n. sp. distribution, along with the other parts of the upper Rockall Bank, is a productive area for demersal gadoids, particularly haddock, but also prominent are blue whiting (Micromesistius poutassou), poor cod (Trisopterus minutus), Norway haddock (Sebastes viviparus), bluemouth (Helicolenus dactylopterus), lesser argentine (Argentina sphyraena) and silvery pout (Gadiculus argenteus thori). In addition, megrim (Lepidorhombus whiffiagonis), grey gurnard (Eutrigla gurnardus), anglerfish (Lophius ssp.) and blue skate (Dipturus flossada) are common (all data available at the public website http://www.ices.dk/ marine-data/data-portals/Pages/DATRAS.aspx).

Invertebrates frequently recorded in the same hauls as $P t$. grayi n. sp. include another sea pen commonly encountered on top of Rockall Bank, Funiculina quadrangularis, and the associated brittlestar Asteronyx lovenii. Others include the scleractinian Caryophyllia smithii, the holothurian Parastichopus tremulus, the crustacean Pagurus forbesii, the asteroids Hippasteria phrygiana, Stichastrella rosea, Astropecten irregularis and Luidia cilaris, the echinoids Gracilechinus spp., and various actinarian spp.

In contrast, Pt. grandis was observed on the Donegal continental slope, Rockall Plateau and Rosemary Seamounts over a depth range of 682-1605 m, with the associated fish and invertebrate assemblages varying greatly with depth. This study also records this species in the southern Norwegian Sea at a depth of 380-404 $\mathrm{m}$, and to the South Iceland at a depth of $1595 \mathrm{~m}$.

\section{Phylogenetic analyses}

In our $m t M u t S+\operatorname{Cox} 1+28 S$ hypothesis (Fig. 5), the sequences obtained for Ptilella grayi n. sp. and Pt. grandis were reunited in a distinct and well-supported clade (Bst $>90 \%$, PP >0.9), far from those related to the available concatenated sequences of Pennatula species, which are also in a well-supported clade (Bst $>90 \%$, PP >0.9). In this phylogenetic hypothesis, species of different genera such as Actinoptilum, Acanthoptilum, Renilla, Ptilosarcus and Gilibelemnon are placed between Ptilella and Pennatula sequences with Ptilella diverging earlier than Pennatula.

Our results demonstrate that Ptilella and its closest morphological genus Pennatula are different by 19 substitutions in mtMutS, 27 in Coxl and 110 in 28S. Moreover, 13 nucleotide mutations in $\mathrm{mtMutS}$ and 20 in Coxl result in silent mutations, while a number of nucleotide mutations (6 in $m t M u t S$ and 7 in Coxl) imply a change of Aa (see Table S2).

An incomplete $m t M u t S$ sequence of Pt. inflata from Namibia was obtained during the molecular works carried out for this paper. Despite several amplifications, it was not possible to obtain a clean sequence that could be used in this study in order to characterize Pt. inflata. However, at least 17 of the 19 substitutions differentiating Ptilella from Pennatula in $m t M u t S$ were in agreement with its placement in Ptilella.

\section{DISCUSSION}

\section{Historical remarks on Ptilella and its type species}

Pennatula grandis was succinctly described by Ehrenberg (1834: 290) based on an old specimen in the Museum of Berlin. Later on, Sars (1846: 17) described and illustrated Pennatula borealis based on material collected in Norway. The latter nomenclature and species were widely accepted thereafter by most of Sars's contemporary octocoral researchers, such as Koren and Danielssen (1856), Milne Edwards and Haime (1857), Herklots (1858), Gray (1860), Richiardi (1869) and Kölliker (1869-1872). 


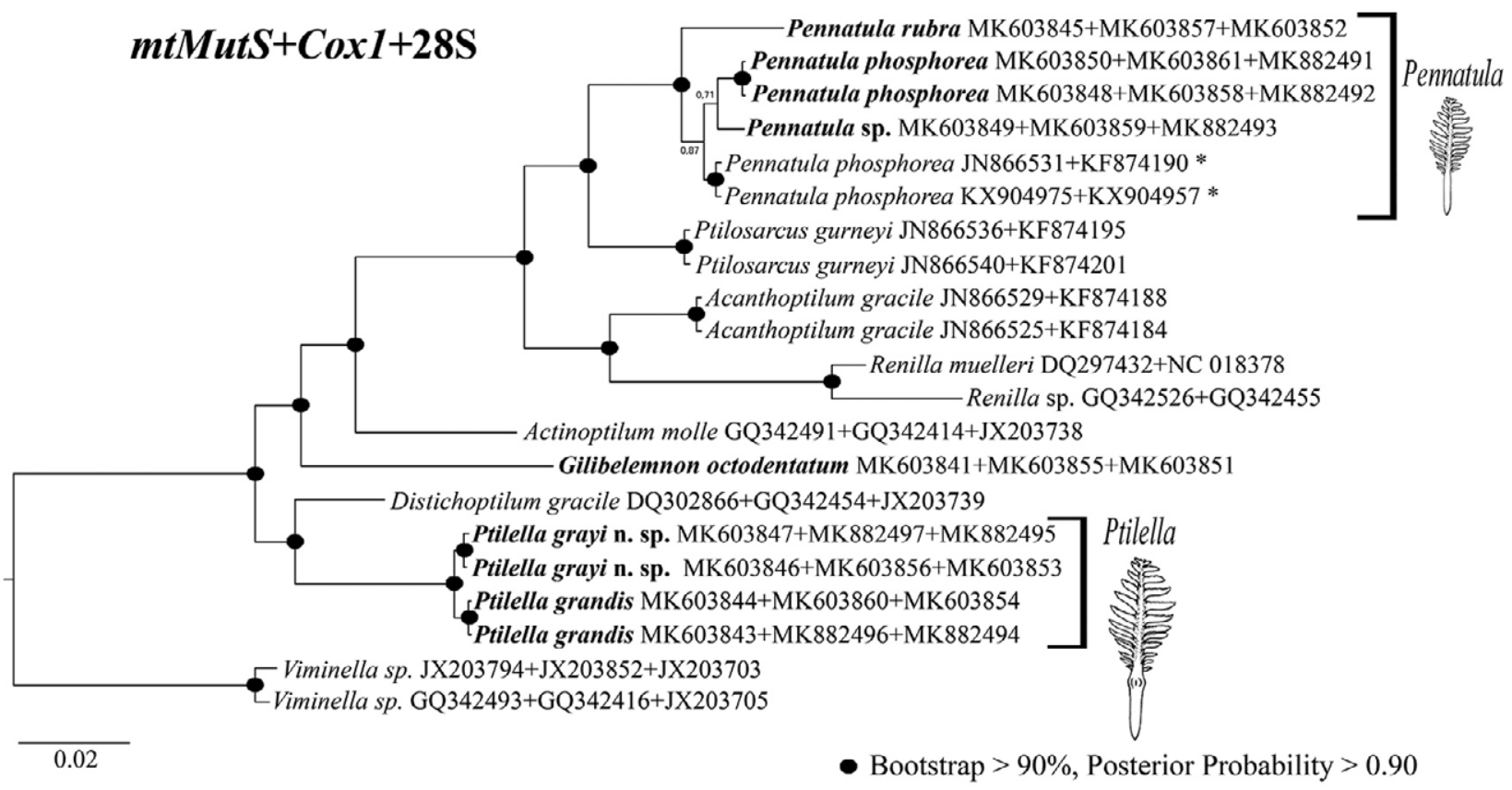

Fig. 5. - Bayesian analysis showing the phylogenetic relationships of Ptilella, Pennatula and other genera and species of sea pens (Clade II of Dolan et al. 2013, and Kushida and Reimer 2018) based on the concatenated mitochondrial sequences $m t M u t S+C o x 1+28 S$. Sequences provided by this study are in bold. See Table 2 for a complete list of species and GenBank accession numbers. The asterisks indicate a pair of sequenced samples from the northeastern Pacific originally identified as Pennatula phosphorea. According to the results of the present analysis, which includes specimens of Pennatula phosphorea from the northeastern Atlantic [the original distribution area indicated by Linnaeus (1758: 818) and Ellis 1764: 420], the identity of the Pacific specimens is considered here as doubtful and deserving of additional morphological and molecular study.

Milne Edwards and Haime (1857: 211) pointed out that Ehrenberg's description of Pennatula grandis accorded well with that of Sars's Pennatula borealis, using this last nomenclature. Richiardi (1869: 31) also considered Pennatula grandis a synonym of Pennatula borealis.

Gray (1870: 21) erected the genus Ptilella based on Pennatula borealis to include a number of distinctive morphological features including "pinnules membranaceous, broad, rounded, fringed with three close parallel series of short polype-cells on the edge".

Kölliker (1872: 136) had the opportunity to examine the original material of Pennatula grandis deposited in the Museum of Berlin. He provided a diagnosis of the species as $P$. borealis and synonymized Ehrenberg's species without being aware of the description of the genus Ptilella. However, this act was contrary to the principle of priority. Kölliker (1872) also described an additional specimen of $350 \mathrm{~mm}$ in length deposited in the collection of the Museum of Copenhagen.

Koren and Danielssen (1874: 422) summarized the discussion on the identity of $P$. grandis and $P$. borealis in favour of the former nomenclature by priority of Ehrenberg's contribution. These authors also recognized the differences of $P$. borealis (as the type species of Ptilella) from all other Pennatula species. Their report is the first to use the nomenclature Ptilella grandis (Ehrenberg). This name was also adopted in a further contribution by the same authors (Koren and Danielssen 1877: 82).

Kölliker (1880: 4), however, did not recognize the genus Ptilella, considering that several rows of autozooids on the ventral border of the polyp leaves and the row of mesozooids on the dorsal edge of the polyp leaves could be included within the variability of the genus Pennatula. Verrill $(1883,1885)$ considered Ptilella a subgenus of Pennatula, as Pennatula (Ptilella) borealis Sars. Subsequent contributions by Grieg (1892: 10), Storm (1901), Jungersen (1904). Kükenthal and Broch (1910) and Broch (1913) do not consider Ptilella at all but simply mention the species as Pennatula grandis.

Despite this, Balss (1910: 54) started to form groups among the species in Pennatula that he considered valid, while Kükenthal and Broch (1911: 350) considered within the genus Pennatula a "Grandis-Gruppe" that brought together $P$. grandis, $P$. naresi and $P$. inflata by the presence of polyp leaves placed in oblique lines and polyps present along at least part of the dorsal margin of the polyp leaves. These authors described a poorly preserved specimen from the North Atlantic as Pennatula aff. inflata, thus clearly establishing the close relationship of $P$. inflata with $P$. grandis and $P$. bellissima. The intrageneric group "Grandis" (without taxonomic category) was not considered in subsequent important contributions (e.g. Kükenthal 1915, Hickson 1916: 181). However, Hickson (1937: 123) again mentioned a "Grandis-Group" when reporting P. inflata from the Maldive Archipelago, considering in that moment the possible synonym of $P$. borealis and $P$. bellissima as $P$. grandis, and even $P$. inflata as a synonym of the latter.

More recently, Ptilella was either considered a synonym of Pennatula (Williams 1995a: 126) or disappeared from the scarce specialized literature that was 
published (e.g. Altuna 2015). Thus, Pennatula grandis is reported in general contributions on North Atlantic benthic communities (e.g. Edinger et al. 2007, Hamoutene et al. 2008, Murillo et al. 2011, Baker et al. 2012, Baillon et al. 2012).

In the present contribution, the genus Ptilella is considered different to Pennatula because of the following set of characters:

1) the lack of zooids along the dorsal track; 2) the autozooids on the margins of polyp leaves being arranged in an oblique group of 3-4 (occasionally 2) polyps, giving the impression of several (3-4) series along the polyp-leaf border; 3 ) a distinctive thickening at the boundary between rachis and peduncle, often giving the appearance of an edged ring while exhibiting different sclerite morphology in the upper and lower part of this thickening; 4) the insertion of polyp leaves on the rachis being distinctly oblique and extending ventrally upward; and 5) DNA sequences ( $m M u t S$, Coxl and 28S) being divergent from those of other pennatulacean genera (see phylogenetic analyses).

In accordance with the differences described, it follows that the diagnosis of Pennatula needs to be amended to include characters that separate it clearly from Ptilella.

\section{Diagnosis of Pennatula (modified from Williams 1995a: 126)}

Colonies pinnate. Symmetry of rachis bilateral throughout. Rachis-peduncle limit just under the lower polyp leaves, as a narrowing, without a distinct thickening or swelling with a prominent edged ring at the rachis-peduncle limit. Axis circular in section, present throughout length of colony. Polyp leaves present, usually large and conspicuous, deltoid, sickle-shaped or fan-shaped. Autozooids in one single row along the ventral edge of polyp leaves. Anthocodiae retractile into permanent spiculiferous calyces. Calyces tubular, with eight terminal teeth. Siphonozooids on rachis, and between polyp leaves. Mesozooids on rachis, or on basal dorsal margin of polyp leaves. Sclerites threeflanged needles on calyces, mesozooids, siphonozooids, inconspicuous three-flanged rods on surface of peduncle, and small ovals in interior of peduncle (mostly $>0.1 \mathrm{~mm}$ long).

Although a revision of the species in the genus is needed, according to Williams (1995a) the following list of species can be tentatively considered valid in the genus Pennatula: P. aculeata Danielssen, 1860 (North Atlantic); P. delicata Tixier-Durivault, 1966 (Madagascar); P. fimbriata Herklots, 1858 (Japan, Philippines); P. indica Thomson and Henderson, 1906 (Indian Ocean); P. phosphorea Linneaus, 1758 (northeastern Atlantic and Mediterranean, Cosmopolitan ?); P. rubra (Ellis, 1761) (Mediterranean Sea); and P. prolifera Jungersen, 1904 (North Atlantic).

As we state above, our phylogenetic hypothesis based on mitochondrial and nuclear markers places the type species of Ptilella, (Pennatula grandis), far from those sequences from the type species of the genus Pennatula, (P. phosphorea), or at least, taking into ac- count that the genus Pennatula is in need of revision from the sequenced species and specimens sharing the morphological characters defined for Pennatula phosphorea in this paper and the most relevant references (e.g. Kükenthal 1915, Kükenthal and Broch 1911) (see Figs 5 and 6).

\section{Comparison of Ptilella species}

In this paper, four Atlantic species are considered to be in the genus Ptilella (Pt. grandis, Pt. grayi n. sp. Pt. inflata, and Pt. bellissima) on the basis of a number of morphological features. Corroborative molecular information is currently available for two of them (Pt. grandis, Pt. grayi), and partially so for Pt. inflata (see above). Molecular grade tissue is, however, lacking from the old single specimen of Pt. bellissima due to the preservation method used.

In the late 19th century, Professor Albert R. von Kölliker described four Pacific sea pen species and ascribed them to the genus Pennatula: $P$. naresi Kölliker (1880: 2), P. pearceyi Kölliker (1880: 4), P. murrayi Kölliker (1880: 5), and P. moseleyi Kölliker (1880: 6). The original descriptions of these species agree with some of the characters considered here for Ptilella: 1 ) the obliquely inserted polyp leaves on the rachis; 2) at least two series of autozooids on the ventral edge of the polyp leaves; 3 ) the dorsal track free of zooids; and 4) mesozooids on the proximal dorsal part of the polyp leaves. While taking into account of the current state of knowledge of these species, their morphological features thus support their tentative inclusion in Ptilella here. However, it is important that their position be reassessed following an improved morphological and molecular understanding of these species in the future.

Ptilella grandis and Pt. grayi n. sp. are clearly differentiated from Pt. bellissima and Pt. inflata by their more rigid and spiculose colonies (especially visible on the upper and lower polyp leaf surfaces), a higher overall number of polyp leaves and a higher number of autozooids per polyp leaf. Moreover, the two former species have a much stronger separation between rachis and peduncle with an edged ring (see Figs 2A, S1A, and S2E for Pt. grayi n. sp.; Figs 7A and 8C for $P t$. grandis). This structure is much more marked in Ptilella grandis and Pt. grayi n. sp. than in Pt. bellissima (see Figs 7C and 8I) and Pt. inflata (see Figs 7B and $8 \mathrm{~F}$ ), where the upper and lower surfaces are more continuous in structure.

Ptilella bellissima was described by Fowler (1888) based on a single specimen from the Bahamas (northwestern Atlantic) as Pennatula bellissima, now deposited in the Natural History Museum in London (BMNH 1880.6.28.1). More than a century later, Castro and Medeiros (2001: 154) described a new species of a large Pennatula (up to $350 \mathrm{~mm}$ in total length) from the Brazilian coast as Pennatula bayeri. After the comparison of both original descriptions and the holotype of Pt. bellissima, we believe P. bayeri to be a junior synonym of Pt. bellissima. As mentioned by Fowler (1888), Castro and Medeiros (2001), and as illustrated in the present paper, Pt. bellissima dif- 

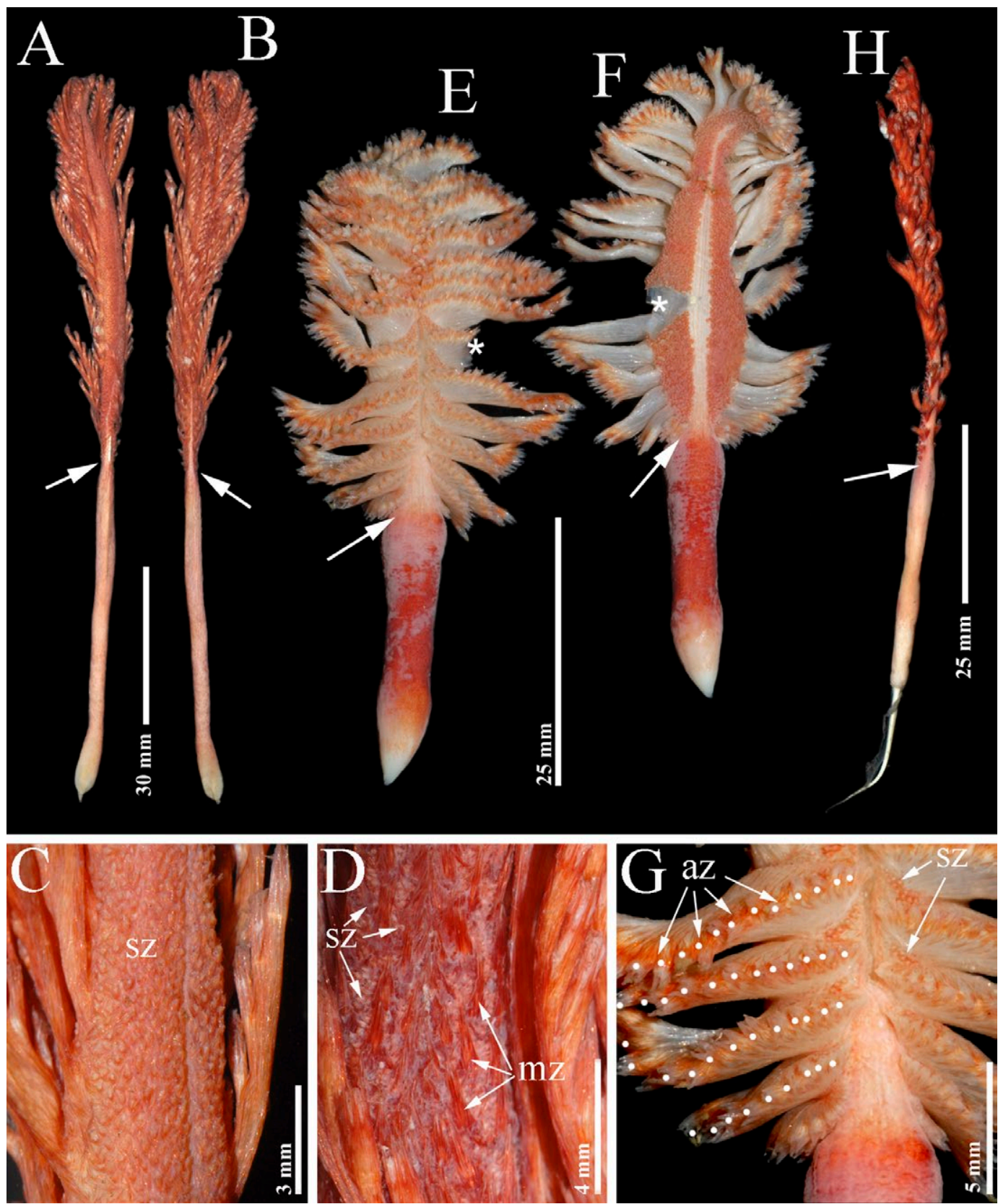

Fig. 6. - Species of the genus Pennatula used in this paper for the comparative morphological and/or molecular study. A-C, Pennatula phosphorea (BECA OPEN-139); A, dorsal view; B, ventral view; $\mathrm{C}$, detail of the distal part of the rachis in dorsal view showing the presence of siphozooids (sz) only covering the dorsal area. Notice the narrow dorsal track. D, Pennatula aculeata (BECA OPEN-206), detail of distal part of the rachis in dorsal view showing the presence of minute siphozooids (sz) among the large mesozooids (mz) covering the dorsal area. E-G, Pennatula rubra (BECA OPEN-453); E, ventral view; F, dorsal view; G, detail of the rachis in ventral view showing the nearly perpendicular orientation of the polyp leaves at their insertion points. Note position of autozooids (indicated by white dots), not to be confused with the siphonozooids (sz), which are present on the rachis limits between two consecutive polyp leaves. H, Pennatula sp. (BECA OPEN-152); G, ventro-lateral view, the polyp leaves are shown oriented distally due to the fixation process. Notice limit between rachis and peduncle (arrowed) in all sequenced colonies. Asterisks indicate damage incurred during the study as part of the examination of sclerome or the tissue sampling process.

fers from Pt. inflata by its slender triangular and less fleshy polyp leaves, and well-spaced (sometimes difficult to follow) groups of 2-3 autozooids along the ventral edge of the polyp leaves. Castro and Medeiros (2001: 157) discussed the possibility of synonymy between Pennatula bayeri $(=P t$. bellissima) and Pt. inflata, but we consider them as two clearly morphologically distinct taxa. It is important that future molecular studies (based on appropriately fixed mate- rial) should further explore the internal relationships of Ptilella species. Particular attention should be paid to further specimens of Pt. bellissima, in order to correctly evaluate the variability in the distribution of mesozooids around the insertion point of the polyp leaves and the autozooids.

The most immediately evident feature differentiating Ptilella grandis and Pt. grayi $\mathrm{n}$. sp. is the colour: dark-red to red-brown both alive and pre- 


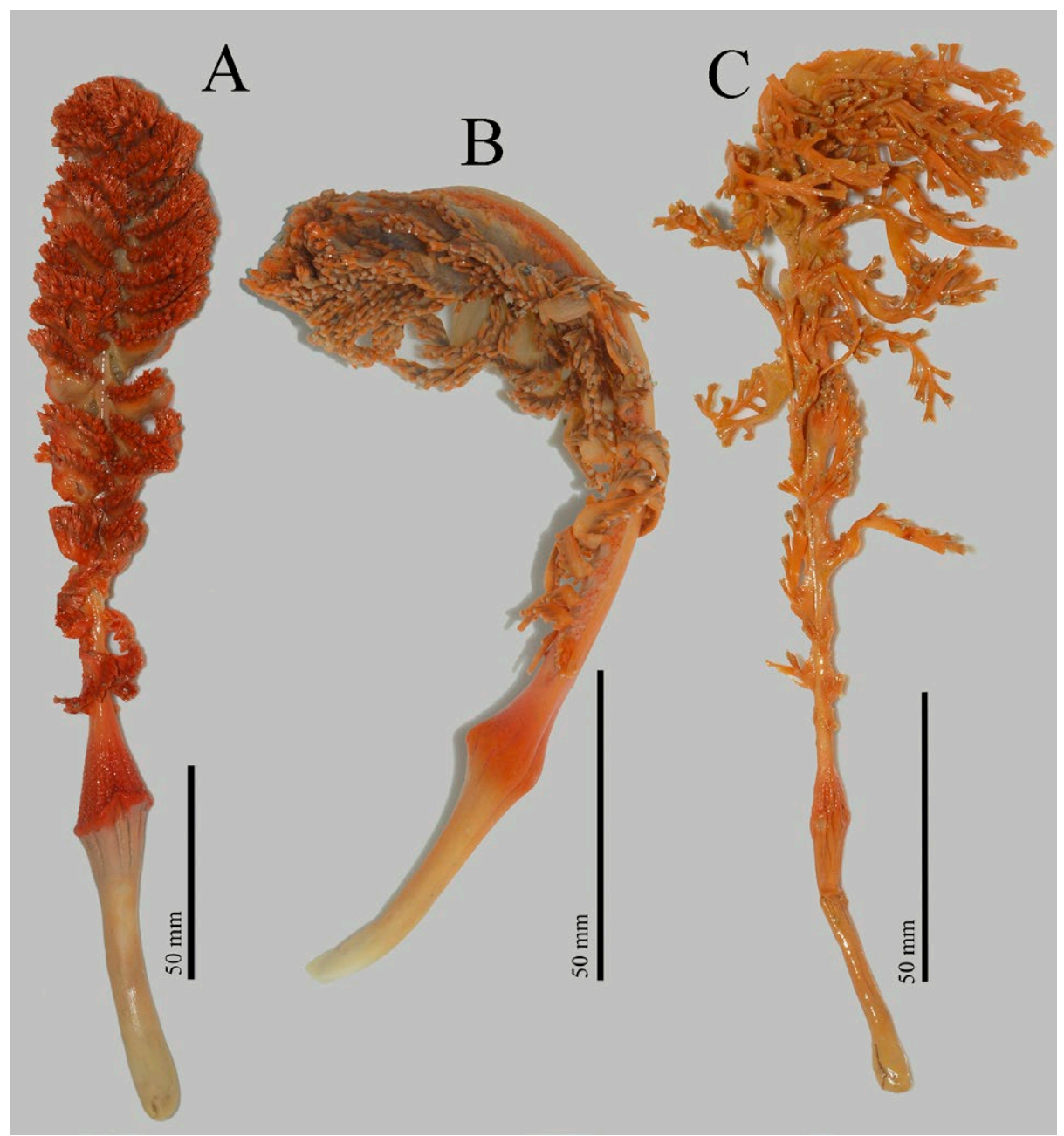

Fig. 7. - Species of the genus Ptilella used in this paper for the comparative study; A, Ptilella grandis (NMS.Z.2019.2.6); B, Ptilella inflata (NMS.Z.2019.2.7); C, Ptilella bellissima (BMNH 1888.6.28.1) holotype.

served in the former but light fleshy to dirty white in the latter in the preserved state and light yellow to light pink in living specimens. In the examined material the maximum observed lengths of sclerites in Pt. grandis and Pt. grayi n. sp. tends to be overall slightly larger in the former species (calyces 1.70 vs. $1.40 \mathrm{~mm}$; mesozooids 1.0 vs. $0.80 \mathrm{~mm}$; siphonozooids 0.80 vs. $0.50 \mathrm{~mm}$; polyp leaves 1.11 vs. 1.40 $\mathrm{mm}$; dorsal track 0.50 vs. 0.40 ; rachis-peduncle limit 0.50 vs. 0.35 above edged ring and 0.16 vs. $0.17 \mathrm{~mm}$ below edged ring).

The molecular comparison of Pt. grayi n. sp. vs Pt. grandis revealed the following substitutions: at the positions $249(\mathrm{~A} / \mathrm{C})$ and $672(\mathrm{C} / \mathrm{A})$ in $m t M u t S$; at the positions $372(\mathrm{~A} / \mathrm{G})$ and $624(\mathrm{C} / \mathrm{A})$ in Coxl; and at the positions $166(\mathrm{C} / \mathrm{A}), 210(\mathrm{~A} / \mathrm{G})$ and $519(\mathrm{G} / \mathrm{C})$ in $28 S$ (see Table S3). In mtMutS, both substitutions imply the change of Aa (Met by Ile, and Phe by Leu, respectively), although in both cases all Aa are nonpolar. In Coxl, both are silent substitutions. Although the genetic distance obtained in $m t M u t S$ did not exceed $0.30 \%$, the more conserved mitochondrial marker Coxl also showed differences between these species, which are additionally supported by the differences in the nuclear $28 S$.
According to our current knowledge, Pt. grayi $\mathrm{n}$. sp. seems to have an overlapping but somewhat more geographically restricted and shallower bathymetric distribution than Pt. grandis (145-389 m and 90-2700 $\mathrm{m}$ in depth, respectively). Moreover, the new species is only known, for the moment, from the NE Atlantic, though Pt. grandis has been reported from both sides of the North Atlantic Ocean. The densities of Pt. grayi n. sp. on Rockall Bank are presently unknown and cannot be inferred from swept area estimates using numbers caught per haul, as it is likely that demersal trawl is an inefficient method of capturing large sea pens that are anchored in the sediment. Moreover, the exact design of trawl used varied with the survey that the specimens were obtained fr.0om.

\section{On the polyphyletic family Pennatulidae and the familial relationships in Clade II}

The traditional family Pennatulidae comprises six genera: Gyrophyllum, Pennatula, Ptilosarcus, Sarcoptilus, Crassophyllum and Pteroeides (Williams 1995a, 1995b). Dolan et al. (2013) showed a consensus phylogenetic tree suggesting a non-monophyletic Pennatulidae. Although the monophyly of Pennatulidae was not 

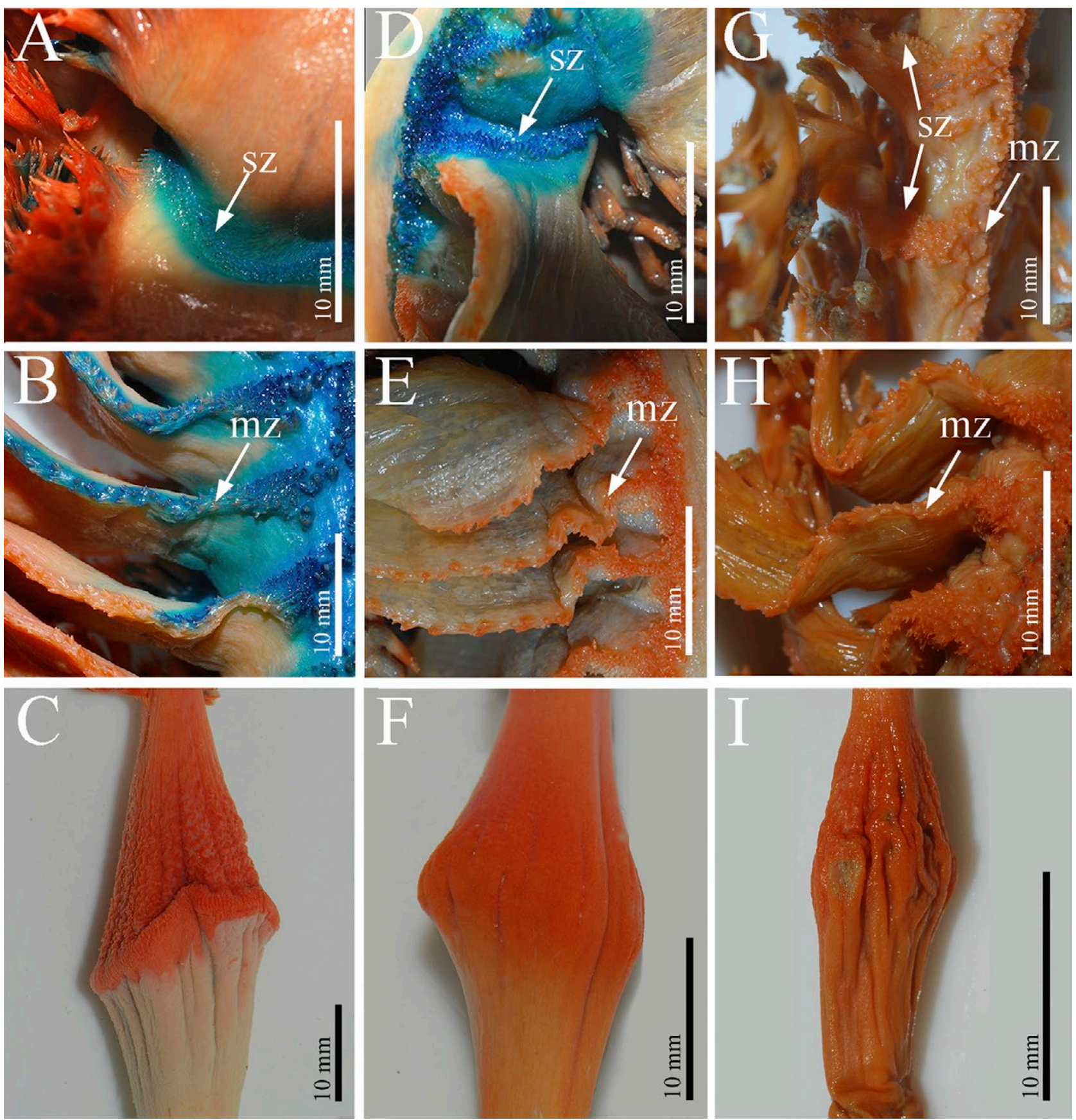

Fig. 8. - Details of different parts of colonies of Ptilella species used for comparison in this study. Vertical rows of images: A-C, Ptilella grandis; D-F, Ptilella inflata; G-I, Ptilella b ellissima. Horizontal rows of images: A, D and G, dorso-lateral view showing arrangement of siphonozooids (sz) in pads at base of polyp leaves; B, E and H, dorsal view of polyp leaves showing mesozooids (mz) on their dorsal edges; $\mathrm{C}, \mathrm{F}$ and I, thickening at the limit between rachis and peduncle.

formally rejected by an SH test, in that study this family formed a non-natural group, placing the genera Pteroeides, Pennatula, and Gyrophyllum into three different clades (Clades I, II and III, respectively). Clade II based on two mitochondrial markers ( $m t M u t S+N D 2)$ included the genera Pennatula, Renilla, Distichoptillum and Protoptilum, the two former genera being sister groups. Later, results offered by Kushida and Reimer (2018) based on those same mitochondrial ( $m t M u t S+N D 2)$ again confirmed the polyphyletic nature of the current Pennatulidae, showing the same distribution of the genera Pteroeides, Pennatula and Gyrophyllum. In that study,
Clade II again included the genus Pennatula as the sister group of Renilla, and both related to genera of different families: Echinoptilum (Echinoptilidae), Stachyptilum (Stachyptilidae), Distichoptilum and Protoptilum (both Protoptilidae), and Scytalium and Stylatula (both Virgulariidae). In our present phylogenetic analyses for Clade II we present a more complete molecular coverage, including two mitochondrial ( $m t M u t S, C o x l)$ markers and a nuclear marker (28S), showing a well-supported genus Pennatula with Ptilosarcus as the sister group, with Renilla being the sister group of Acanthoptillum (see Fig. 5). Pennatula species were well separated from 
the resurrected genus Ptilella, which diverges early. Future sea pen studies utilizing a more complete set of taxonomic units (families, genera and species) and molecular markers may completely change our previous understanding of the distribution of genera among all the possible familial units in this specialized group of octocorals. We recognise the current incomplete and unstable state of taxonomic knowledge of the Pennatulidae and our placement of Ptilella within this family is to be regarded as tentative. We consider this as pending a thoroughly comprehensive review that will also achieve the segregation of diagnostic morphological characters across those well supported familial units.

\section{ACKNOWLEDGEMENTS}

The authors would like to express their gratitude to Miranda Lowe (British Museum of Natural History) for the loan of the holotype of Pennatula bellissima. Many thanks to the colleagues and crew of the MRV Scotia over the many cruises involved and particularly to several who dedicatedly examined the net a great many times for specimens: Matthew Kinghorn, Hubert Wozniak, Peter Brown and Christopher Boagey. Our thanks are also addressed to the officers and crew and to many colleagues for facilitating access to the collections or for their help on board during the cruises Polarstern ANT XXIII/8 (Antarctic Peninsula and eastern Weddell Sea), BIOROSS Tangaroa 0402 (Ross Sea, Antarctica), BENGUELA VIII (Namibia, southeastern Atlantic), INDEMARES Chica (Gulf of Cadiz, NE Atlantic), and INDEMARES Alborán (Mediterranean), where part of the comparative materials used in morphological and molecular comparisons were collected. Part of the material of Pt. grandis consulted in this paper was provided by the BIOICE project. We express our gratitude to Drs Gudmundur Vidir, Gudmundur Gudmundsson and Jörundur Svavarsson, and to the staff of the BIOICE project for allowing us to study the BIOICE octocoral material at the Sandgerdi Marine Centre in Iceland. PJL-G acknowledges financial support for a visit to the Sandgerdi Marine Centre (Iceland) under the EC-funded TMR BIOICE Large-Scale Facility Programme. Antarctic specimens of Pennatula were consulted within the project CTM2017-83920-P (DIVERSICORAL) funded by the Spanish Ministry of Economy, Industry and Competitiveness. The authors are also grateful for the criticisms and suggestions provided by three anonymous referees and the editor of SM. The use of the Scanning Electron Microscopy facilities of the University of Seville were made possible thanks to a grant to PJL-G from VIPPIT-2017-1.5 (VI Plan Propio de Investigación de la Universidad de Sevilla, Vicerrectorado de Investigación).

\section{REFERENCES}

Altuna A. 2015. Identificación de las especies ibéricas del género Pennatula L., 1758 (Octocorallia: Pennatulacea). Campañas Demersales, Ecomarg, Indemares y Medits. Insub, 11 pp.

Baillon S., Hamel J.F., Warehem V.E., et al. 2012. Deep cold-water corals as nurseries for fish larvae. Front. Ecol. Environ. 10: 351-356. https://doi.org/10.1890/120022

Baker K.D., Wareham V.E., Snelgrove P.V.R, et al. 2012. Distributional patterns of deep-sea coral assemblages in three submarine canyons off Newfoundland, Canada. Mar. Ecol. Prog. Ser. 445: 235-249.

https://doi.org/10.3354/meps09448

Balss H. 1910. Japanische Pennatuliden. In: Doflein F. (eds), Beiträge zur Naturgeschichte Ostasiens: Abhandlungen der Mathematisch-Physischen Classe der Königlich Sächsischen Gesellschaft der Wissenschaften 10 suppl.: 1-106.

Bayer F.M. 1956. Octocorallia. In: Moore R.C. (eds), Treatise on invertebrate paleontology. Part F. Coelenterata. Geol. Soc. America Univ. Kansas Press. New York and Lawrence Kansas, pp. 166-231.

Bayer F.M., Stefani J. 1988. Primnoidae (Gorgonacea) de NouvelleCaledonie. Bull. Mus. Natl. Hist. Nat. Paris 10(A)3: 449-476.

Bayer F.M., Grasshoff M., Verseveldt J. 1983. Illustrated trilingual glossary of morphological and anatomical terms applied to Octocorallia. E. J. Brill/ Dr. Backhuys, Leiden. 75 pp.

Broch H. 1913. Die Alcyonarien des Trondhjemsfjordes, III: Pennatulacea; IV. Biogeographische Übersicht. Norske Videnskabers Selskab, Trondheim. Skrifter 1912(10): 1-59.

Brockman S.A., McFadden C.S. 2012. The mitochondrial genome of Paraminabea aldersladei (Cnidaria: Anthozoa: Octocorallia) supports intramolecular recombination as the primary mechanism of gene rearrangement in octocoral mitochondrial genomes. Genome Biol. Evol. 4(9): 882-894. https://doi.org/10.1093/gbe/evs074

Brummitt R.K. 2002. How to chop up a tree. Taxon 51: 31-41. https://doi.org/10.2307/1554961

Castro C.B., Medeiros M.S. 2001. Brazilian Pennatulacea (Cnidaria: Octocorallia). Bull. Biol. Soc. Wash. 10: 140-159.

Crisp M.D., Chandler G.T. 1996. Paraphyletic species. Telopea 6: 813-844. https://doi.org/10.7751/telopea19963037

Dolan E., Tyler P.A., Yesson C., et al. 2013. Phylogeny and systematics of deep-sea sea pens (Anthozoa: Octocorallia: Pennatulacea). Mol. Phylogenet. Evol. 69: 610-618. https://doi.org/10.1016/j.ympev.2013.07.018

Done T.J. 1999. Coral Community Adaptability to Environmental Change at the Scales of Regions, Reefs and Reef Zones. Am. Zool. 39: 66-79. https://doi.org/10.1093/icb/39.1.66

Ellis J. 1764. An account of the sea pen, or Pennatula phosphorea of Linnaeus; likewise a description of a new species of sea pen, found on the coast of South-Carolina, with observations on sea-pens in general. In a letter to the honourable Coote Molesworth, Esq; M.D. and F.R.S. from John Ellis, esq; F.R.S. and member of the Royal Academy of Upsal. Phil. Trans. R. Soc. Lond. 53: 419-435. https://doi.org/10.1098/rstl.1763.0054

Edinger E.N., Wareham V.E., Haedrich R.L. 2007. Patterns of groundfish diversity and abundance in relation to deep-sea coral distributions in Newfoundland and Labrador waters. Bull. Mar. Sci. 81: 101-122.

Ehrenberg C.G. 1834. Beitrage zur physiologishcen Kenntniss der Corallenthiere im allgemeinen, und besonders des rothen Meeres, nebst einem Versuche zur physiologischen Systematik derselben. Abh. Königl. Akad Wiss Berlin. Aus dem Jahre. Erster Theil 1832: 225-380.

Everett M.V., Park L.K., Berntson E.A., et al. 2016. Large-scale genotyping-by-sequencing indicates high levels of gene flow in the deep-sea octocoral Swiftia simplex (Nutting 1909) on the west coast of the United States. PloS ONE 11: e0165279. https://doi.org/10.1371/journal.pone.0165279

Fleck G., Brenk M., Misof B. 2008. Larval and molecular characters help to solve phylogenetic puzzles in the highly diverse dragonfly family Libellulidae (Insecta: Odonata: Anisoptera): The Tetrathemistinae are a polyphyletic group. Org. Divers. Evol. 8: $1-6$. https://doi.org/10.1016/j.ode.2006.08.003

Fowler G.H. 1888. On a new Pennatula from the Bahamas. Proc. Zool. Soc. Lond. 1888: 135-140.

France S.C., Hoover L.L. 2002. DNA sequences of the mitochondrial COI gene have low levels of divergence among deep-sea octocorals (Cnidaria: Anthozoa). Hydrobiologia 471: 149-155. https://doi.org/10.1023/A:1016517724749

Gray J.E. 1860. Revision of the family Pennatulidæ, with descriptions of some new species in the British Museum. J. Nat. Hist. 5: $20-25$. https://doi.org/10.1080/00222936008697169 
Gray J.E. 1870. Catalogue of sea-pens or Pennatulariidae in the collection of the British Museum. British Museum. London, 40 pp. https://doi.org/10.5962/bhl.title.11307

Grieg J. 1892. Ovsersigt over Norges pennatulider. In: Bergens Museums Aarsberetning for 1891, pp. 1-22.

https://archive.org/details/bergensmuseum18911893berg/page/n5

Hamoutene D., Puestow T., Miller-Banoub J., et al. 2008. Main lipid classes in some species of deep-sea corals in the Newfoundland and Labrador region (Northwest Atlantic Ocean). Coral Reefs 27: $237-246$

https://doi.org/10.1007/s00338-007-0318-7

Herklots J.A. 1858. Notices pour servir à l'étude des polypiers nageurs ou pennatulidés. Bijdragen tot de Dierkunde. 7: 1-31. https://doi.org/10.1163/26660644-00701001

Hickson S.J. 1916. The Pennatulacea of the Siboga Expedition, with a general survey of the order. Siboga Expeditie Monographs 14, Livr. 77: 1-265.

Hickson S.J. 1937. The Pennatulacea. Scientific Rep. John Murray Expedition, 1933-v1934. 4(5): 109-130.

Huelsenbeck J.P., Ronquist F. 2001. MRBAYES: Bayesian inference of phylogenetic trees. Bioinformatics 17: 754-755. https://doi.org/10.1093/bioinformatics/17.8.754

Jungersen H.F.E. 1904. Pennatulida. Danish Ingolf-Expedition. 5: $1-95$.

Kölliker R.A. 1869-72. Anatomisch-Systematische Beschreibung der Alcyonararien. I. Die Pennatuliden. Abh. Senckenb. Naturforsch. Ges. 7-8: 1-458.

Kölliker R.A. 1872. Morphologie und Entwickelungsgeschichte des Pennatulidenstammes nebst allgemeinen Betrachtungen zu Descendenzlehre. Christian Winter, Frankfurt am Main, 87 pp.

Kölliker R.A. 1880. Report on the Pennatulida dredged by H. M. S. Challenger during the years 1873-1876. Report of the Scientific Results of the Voyage of H. M. S. Challenger during the years 1873-76. Zoology 1: 1-41.

Koren J., Danielssen D.C. 1856. Virgularia Christii K. and D. In: Sars M., Koren J., Danielssen D.C. (eds), Fauna Littoralis Norvegiae 2: 91-93.

Koren J., Danielssen D.C. 1874. Bidrag til de ved den norske Kyst levende Pennatuliders Naturhistorie. Nyt Mag. Naturvid. 12: 422-427.

Koren J., Danielssen D.C. 1877. Contribution to the natural history of the Pennatulidae living on the Norwegian coast. In: Sars M., Koren J., et al. (eds), Fauna Littoralis Norvegiae 3: 82-102.

Kükenthal W. 1910. Pennatuliden der Deutschen Tiefsee-Expedition. Zool. Anz. 36: 51-58.

Kükenthal W. 1915. Pennatularia. Das Tierreich. 43: 1-132. Verlag von R. Friedländer und Sohn, Berlin.

Kükenthal W., Broch H. 1910. System und Stammesgeschichte der Seefedem. Zool. Anz. 36: 222-230.

Kükenthal W., Broch H. 1911. Pennatulacea. Wissenschaftliche Ergebnisse der deutschen Tiefsee-Expedition "Valdivia" 13: 113-576.

Kushida Y., Reimer J.D. 2018. Molecular phylogeny and diversity of sea pens (Cnidaria: Octocorallia: Pennatulacea) with a focus on shallow water species of the northwestern Pacific Ocean. Mol. Phylogenet. Evol. 131: 233-244. https://doi.org/10.1016/j.ympev.2018.10.032

Linnaeus C. 1758. Systema naturae. Editio decima, reformata. Holmiae (Salvii). 824 pp.

López-González P.J., Williams G.C. 2002. A new genus and species of sea pen (Octocorallia: Pennatulacea: Stachyptilidae) from the Antarctic Peninsula. Invertebr. Syst. 16: 919-929. https://doi.org/10.1071/IT01027

López-González P.J., Gili J.M., Williams G.C. 2001. New records of Pennatulacea (Anthozoa: Octocorallia) from the African Atlantic coast, with description of a new species and a zoogeographic analysis. Sci. Mar. 65: 59-74. https://doi.org/10.3989/scimar.2001.65n159

Lowther P.E., Fraga R., Schulenberg T.S., et al. 2004. Nomenclatural solution for a polyphyletic Agelaius. Bull. Br. Ornithol. Club. 124: 171-175.

McFadden C.S., van Ofwegen L.P. 2012. Stoloniferous octocorals (Anthozoa, Octocorallia) from South Africa, with descriptions of a new family of Alcyonacea, a new genus of Clavulariidae, and a new species of Cornularia (Cornulariidae). Invertebr. Syst. 26: 331-356. https://doi.org/10.1071//S12035

McFadden C.S., van Ofwegen L.P. 2013. A second, cryptic species of the soft coral genus Incrustatus (Anthozoa: Octocorallia: Clavulariidae) from Tierra del Fuego, Argentina revealed by
DNA barcoding. Helgol. Mar. Res. 67: 137-147. https://doi.org/10.1007/s10152-012-0310-7

McFadden C.S., Tullis I.D., Hutchinson M.B., et al. 2004. Variation in coding (NADH dehydrogenase subunits 2, 3, and 6) and noncoding intergenic spacer regions of the mitochondrial genome in Octocorallia (Cnidaria: Anthozoa). Mar. Biotechnol. 6: 516-526. https://doi.org/10.1007/s10126-002-0102-1

McFadden C.S., France S.C., Sánchez J.A., et al. 2006. A molecular phylogenetic analysis of the Octocorallia (Cnidaria: Anthozoa) based on mitochondrial protein-coding sequences. Mol. Phylogenet. Evol. 41: 513-527. https://doi.org/10.1016/j.ympev.2006.06.010

McFadden C.S., Brown A.S., Brayton C., et al. 2014. Application of DNA barcoding in biodiversity studies of shallow-water octocorals: molecular proxies agree with morphological estimates of species richness in Palau. Coral Reefs 33: 275-286. https://doi.org/10.1007/s00338-013-1123-0

Milne Edwards H., Haime J. 1857. Histoire naturelle des coralliaires ou polypes proprement dits. Librairie Encyclopédique de Roret, Paris. 326 pp. https://doi.org/10.5962/bhl.title.11574

Murillo F.J., Durán M.P., Altuna A., et al. 2011. Distribution of deep-water corals of the Flemish Cap, Flemish Pass, and the Grand Banks of Newfoundland (Northwest Atlantic Ocean): interaction with fishing activities. ICES J. Mar. Sci. 68: 319-332. https://doi.org/10.1093/icesjms/fsq071

OSPAR Commission. 2010. Background Document for Sea pen and Burrowing megafauna communities. Biodiversity Series. Ospar Convention for the Protection of the Marine Environment of the Northeast Atlantic.

Richiardi S. 1869. Monografía della famiglia dei Pennatularii. Ser. 2, Archivio per la zoología, l'anatomia e la fisiología. Vol. 1, Fava e Garagnani, Bologna, 150 pp. https://doi.org/10.5962/bhl.title.9116

Ronquist F., Huelsenbeck J.P. 2003. MrBayes 3: Bayesian phylogenetic inference under mixed models. Bioinformatics 19: 1572-1574. https://doi.org/10.1093/bioinformatics/btg180

Sale P.F. 1977. Maintenance of high diversity in coral reef fish communities. Am. Nat. 111: 337-359. https://doi.org/10.1086/283164

Sammarco P.W., Coll J.C. 1992. Chemical adaptations in the Octocorallia: evolutionary considerations. Mar. Ecol. Prog. Ser. 88: 93-104. https://doi.org/10.3354/meps088093

Sánchez J.A., McFadden C.S., France S.C., et al. 2003. Molecular phylogenetic analyses of shallow-water Caribbean octocorals. Mar. Biol. 142: 975-987. https://doi.org/10.1007/s00227-003-1018-7

Sars M. 1846. Beschreibung der Pennatula borealis, einer neuen Seefeder. In: Fauna littoralis Norvegiae: oder Beschreibung und Abbildungen neuer oder wenig bekannten Seethiere, nebst Beobachtungen über die Organisation, Lebensweise u. Entwickelung derselben. Johann Dahl, Christiana. 1: 17-19. https://doi.org/10.5962/bhl.title.57954

Storm V. 1901. Oversigt over Throndheimsfjordens fauna (med et kort). Trondhjems Biologiske Station, Meddelelser fra stationsanleggets arbeidskomite. H. Moe's Bog \& Accidentstrykkeri, Trondhjem, $20 \mathrm{pp}$.

Tamura K., Peterson D., Peterson N., et al. 2011. MEGA5: Molecular Evolutionary Genetics Analysis using Maximum Likelihood, Evolutionary Distance, and Maximum Parsimony Methods. Mol. Biol. Evol. 28: 2731-2739. https://doi.org/10.1093/molbev/msr121

Verrill A.E. 1883. Report on the Anthozoa, and on some additional species dredged by the "Blake" in 1877-1879, and by the U. S. Fish Commission steamer "Fish Hawk" in 1880-82. Bull. Mus. Comp. Zool. 11: 1-72.

Verrill A.E. 1885. Results of the explorations made by the steamer Albatross off the northern coast of the United States in 1883. Ann. Rep. US Comm. Fish. 1883: 503-699. https://doi.org/10.5962/bhl.title.12059

Wheeler Q.D., Nixon K.C. 1990. Another way of looking at the species problem: a reply to de Queiroz and Donoghue. Cladistics. 6: $77-81$. https://doi.org/10.1111/j.1096-0031.1990.tb00526.x

Williams G.C. 1995a. Living genera of sea pens (Coelenterata: Octocorallia: Pennatulacea): illustrated key and synopses. Zool. J. Linn. Soc. 113: 93-140. 
https://doi.org/10.1006/zjls.1995.0004

Williams G.C. 1995b. The enigmatic sea pen genus Gyrophyllum - A phylogenetic reassessment and description of $G$. sibogae from Tasmanian waters (Coelenterata: Octocorallia). Proc. Cal. Acad. Sci. 48: 315-328.

Williams G.C. 2011. The Global Diversity of Sea Pens (Cnidaria: Octocorallia: Pennatulacea). PLoS ONE 6: e22747. https://doi.org/10.1371/journal.pone.0022747

Williams G.C. 2015. A new genus and species of pennatulacean octocoral from equatorial West Africa (Cnidaria, Anthozoa, Virgulariidae). Zookeys 546: 39-50. https://doi.org/10.3897/zookeys.546.6344

Williams G.C., Alderslade P. 2011. Three new species of pennatulacean octocorals with the ability to attach to rocky substrata (Cnidaria: Anthozoa: Pennatulacea). Zootaxa 3001: 33-48. https://doi.org/10.11646/zootaxa.3001.1.2

\section{SUPPLEMENTARY MATERIAL}

The following supplementary material is available through the online version of this article and at the following link:

http://scimar.icm.csic.es/scimar/supplm/sm04845esm.pdf

Table S1. - Data associated with all hauls where Ptilella grayi n. sp. and Ptilella grandis were observed, including the number of colonies recorded at each.

Table S2. - Nucleotide substitution implying amino acid changes in the mitochondrial loci mtMutS and Coxl, between the se- quences of Ptilella and Pennatula used in the molecular analyses, once homologous sites of a datamatrix including Ptilella and Pennatula sequences are aligned (see Table 2 and Fig. 5).

Table S3. - Nucleotide and amino acid differences in the mitochondrial loci mtMutS and Coxl, and nucleotide differences in the nuclear $28 S$ between Ptilella grayi n. sp. and Pt. grandis. Based on a datamatrix including only Ptiella and Pennatula species (see Table 2 and Fig. 5).

Fig. S1. - Ptilella grayi n. sp. Paratype (NMS.Z.2019.2.3). A, whole colony; $\mathrm{B}$, dorsal view of polyp leaves and naked dorsal track showing the location of mesozooids; $\mathrm{C}$, detail of autozooids on the ventral edge of the polyp leaves; D, detail of oblique rows of autozooids, sectioned basally, stained with methylene blue to increase contrast.

Fig. S2. - Ptilella grayi n. sp. Paratype (NMS.Z.2019.2.3). A, polyp-leaf sectioned from the base, lateral view; B, detail of dorsal area of a polyp-leaf showing autozooids (az) and mesozooids $(\mathrm{mz})$, and distal area free of zooids $(*)$; C, detail of dorsal basal part of polyp leaves showing siphonozooids (sz) and mesozooids (mz); D, detail of arrangement of siphonozooids (sz) in pad at the base of a polyp leaf; E, distinctive thickening at the rachis-peduncle limit.

Fig. S3. - Ptilella grayi n. sp. Paratype (NMS.Z.2019.2.3). SEM photographs of sclerites. A, calyces; B, mesozooids; C, siphonozooids; D, polyp leaves; E, dorsal track; F, rachis-peduncle limit, above edged ring (upper row) and below edged ring (lower row). 
Resurrection of the sea pen genus Ptilella Gray, 1870 and description of Ptilella grayi n. sp. from the NE Atlantic (Octocorallia: Pennatulacea)

Francisco J. García-Cárdenas, Jim Drewery, Pablo J. López-González

Supplementary material 
S2 • F.J. García Cárdenas et al..

Table S1. - Data associated with all hauls where Ptilella grayi n. sp. and Ptilella grandis were observed including the number of colonies recorded at each.

\begin{tabular}{|c|c|c|c|c|c|c|c|}
\hline cies & Cruise & Cruise no (haul) & Area & $\begin{array}{l}\text { Coordinates } \\
\text { Start - Stop }\end{array}$ & $\begin{array}{l}\text { Depth } \\
\text { range }(\mathrm{m})\end{array}$ & Date & $\begin{array}{l}\text { No. colo- } \\
\text { nies }\end{array}$ \\
\hline Ptilella grayi $\mathrm{n} . \mathrm{sp}$. & $\begin{array}{l}\text { Rockall Haddock } \\
\text { Survey } 2005\end{array}$ & 1205S (S05357) & $\begin{array}{c}\text { Rockall Bank, NE } \\
\text { Atlantic }\end{array}$ & $\begin{array}{c}56^{\circ} 35.49 \mathrm{~N} 14^{\circ} 31.57 \mathrm{~W}- \\
56^{\circ} 36.52 \mathrm{~N} 14^{\circ} 28.72 \mathrm{~W}\end{array}$ & $197-198$ & 06-Sep-05 & 3 \\
\hline Ptilella grayi $\mathrm{n} . \mathrm{sp}$. & $\begin{array}{l}\text { Rockall Haddock } \\
\text { Survey } 2007\end{array}$ & 1207S (S07371) & $\begin{array}{c}\text { Rockall Bank, NE } \\
\text { Atlantic }\end{array}$ & $\begin{array}{l}57^{\circ} 09.39 \mathrm{~N} 14^{\circ} 12.16 \mathrm{~W}- \\
57^{\circ} 09.59 \mathrm{~N} 14^{\circ} 08.94 \mathrm{~W}\end{array}$ & $166-170$ & 13-Sep-07 & 1 \\
\hline Ptilella grayi $\mathrm{n} . \mathrm{sp}$. & $\begin{array}{l}\text { Rockall Haddock } \\
\text { Survey } 2007\end{array}$ & 1207S (S07386) & $\begin{array}{c}\text { Rockall Bank, NE } \\
\text { Atlantic }\end{array}$ & $\begin{array}{l}56^{\circ} 32.78 \mathrm{~N} 14^{\circ} 32.25 \mathrm{~W}- \\
56^{\circ} 31.32 \mathrm{~N} 14^{\circ} 34.00 \mathrm{~W}\end{array}$ & $198-203$ & 12-Sep-07 & 2 \\
\hline Ptilella grayi $\mathrm{n} . \mathrm{sp}$. & $\begin{array}{l}\text { Rockall Haddock } \\
\text { Survey } 2008\end{array}$ & $1108 \mathrm{~S}$ (S08358) & $\begin{array}{c}\text { Rockall Bank, NE } \\
\text { Atlantic }\end{array}$ & $\begin{array}{l}56^{\circ} 28.03 \mathrm{~N} 14^{\circ} 41.91 \mathrm{~W}- \\
56^{\circ} 27.82 \mathrm{~N} 14^{\circ} 38.40 \mathrm{~W}\end{array}$ & 199-202 & 06-Sep-08 & 5 \\
\hline Ptilella grayi $\mathrm{n} . \mathrm{sp}$. & $\begin{array}{l}\text { Rockall Haddock } \\
\text { Survey } 2008\end{array}$ & $1108 \mathrm{~S}$ (S08360) & $\begin{array}{c}\text { Rockall Bank, NE } \\
\text { Atlantic }\end{array}$ & $\begin{array}{l}56^{\circ} 35.43 \mathrm{~N} 14^{\circ} 32.20 \mathrm{~W}- \\
56^{\circ} 36.37 \mathrm{~N} 14^{\circ} 29.54 \mathrm{~W}\end{array}$ & 197-199 & 06-Sep-08 & 1 \\
\hline Ptilella grayi n. sp. & $\begin{array}{l}\text { Rockall Anglerfish } \\
\text { Survey } 2009\end{array}$ & 0409S (S09168) & $\begin{array}{c}\text { Rockall Bank, NE } \\
\text { Atlantic }\end{array}$ & $\begin{array}{l}56^{\circ} 43.54 \mathrm{~N} 14^{\circ} 34.52 \mathrm{~W}- \\
56^{\circ} 46.84 \mathrm{~N} 14^{\circ} 33.03 \mathrm{~W}\end{array}$ & $187-195$ & 5-May-09 & 1 \\
\hline Ptilella grayi n. sp. & $\begin{array}{l}\text { Rockall Anglerfish } \\
\text { Survey } 2009\end{array}$ & 0409S (S09169) & $\begin{array}{c}\text { Rockall Bank, NE } \\
\text { Atlantic }\end{array}$ & $\begin{array}{l}56^{\circ} 37.05 \mathrm{~N} 14^{\circ} 25.39 \mathrm{~W}- \\
56^{\circ} 36.63 \mathrm{~N} 14^{\circ} 31.29 \mathrm{~W}\end{array}$ & $191-200$ & 5-May-09 & 3 \\
\hline Ptilella grayi $\mathrm{n} . \mathrm{sp}$. & $\begin{array}{l}\text { Rockall Anglerfish } \\
\text { Survey } 2009\end{array}$ & 0409S (S09170) & $\begin{array}{c}\text { Rockall Bank, NE } \\
\text { Atlantic }\end{array}$ & $\begin{array}{l}57^{\circ} 17.82 \mathrm{~N} 14^{\circ} 14.45 \mathrm{~W}- \\
57^{\circ} 14.44 \mathrm{~N} 14^{\circ} 14.93 \mathrm{~W}\end{array}$ & $170-178$ & 6-May-09 & 3 \\
\hline Ptilella grayi $\mathrm{n} . \mathrm{sp}$. & $\begin{array}{l}\text { Rockall Anglerfish } \\
\text { Survey } 2009\end{array}$ & 0409S (S09172) & $\begin{array}{c}\text { Rockall Bank, NE } \\
\text { Atlantic }\end{array}$ & $\begin{array}{l}57^{\circ} 22.21 \mathrm{~N} 13^{\circ} 52.59 \mathrm{~W}- \\
57^{\circ} 21.17 \mathrm{~N} 13^{\circ} 58.32 \mathrm{~W}\end{array}$ & $145-153$ & 6-May-09 & 1 \\
\hline Ptilella grayi n. sp. & $\begin{array}{l}\text { Rockall Haddock } \\
\text { Survey } 2009\end{array}$ & 1209S (S09339) & $\begin{array}{c}\text { Rockall Bank, NE } \\
\text { Atlantic }\end{array}$ & $\begin{array}{l}57^{\circ} 03.65 \mathrm{~N} 14^{\circ} 08.69 \mathrm{~W}- \\
57^{\circ} 02.74 \mathrm{~N} 14^{\circ} 11.61 \mathrm{~W}\end{array}$ & $167-191$ & 07-Sep-09 & 1 \\
\hline Ptilella grayi n. sp. & $\begin{array}{l}\text { Rockall Haddock } \\
\text { Survey } 2009\end{array}$ & 1209S (S09347) & $\begin{array}{c}\text { Rockall Bank, NE } \\
\text { Atlantic }\end{array}$ & $\begin{array}{l}56^{\circ} 36.11 \mathrm{~N} 14^{\circ} 29.97 \mathrm{~W}- \\
56^{\circ} 35.20 \mathrm{~N} 14^{\circ} 32.73 \mathrm{~W}\end{array}$ & 194-201 & 09-Sep-09 & 1 \\
\hline Ptilella grayi $\mathrm{n} . \mathrm{sp}$. & $\begin{array}{l}\text { Rockall Haddock } \\
\text { Survey } 2009\end{array}$ & 1209S (S09349) & $\begin{array}{c}\text { Rockall Bank, NE } \\
\text { Atlantic }\end{array}$ & $\begin{array}{l}56^{\circ} 43.69 \mathrm{~N} 14^{\circ} 30.18 \mathrm{~W}- \\
56^{\circ} 44.51 \mathrm{~N} 14^{\circ} 29.62 \mathrm{~W}\end{array}$ & 192-198 & 09-Sep-09 & 2 \\
\hline Ptilella grayi n. sp. & $\begin{array}{l}\text { Rockall Haddock } \\
\text { Survey } 2009\end{array}$ & 1209S (S09350) & $\begin{array}{c}\text { Rockall Bank, NE } \\
\text { Atlantic }\end{array}$ & $\begin{array}{l}56^{\circ} 47.90 \mathrm{~N} 14^{\circ} 05.97 \mathrm{~W}- \\
56^{\circ} 46.39 \mathrm{~N} 14^{\circ} 08.07 \mathrm{~W}\end{array}$ & 193 & 09 & 1 \\
\hline Ptilella grayi & $\begin{array}{l}\text { Rockall Anglerfish } \\
\text { Survey } 2010\end{array}$ & 0410S (S10150) & $\begin{array}{c}\text { Rockall Bank, NE } \\
\text { Atlantic }\end{array}$ & $\begin{array}{l}56^{\circ} 25.22 \mathrm{~N} 15^{\circ} 14.67 \mathrm{~W}- \\
56^{\circ} 22.91 \mathrm{~N} 15^{\circ} 18.75 \mathrm{~W}\end{array}$ & $238-262$ & 06-Apr-10 & 1 \\
\hline Ptilella grayi $\mathrm{n} . \mathrm{sp}$. & $\begin{array}{l}\text { Rockall Haddock } \\
\text { Survey } 2011\end{array}$ & 0911S (S11426) & $\begin{array}{c}\text { Rockall Bank, NE } \\
\text { Atlantic }\end{array}$ & $\begin{array}{c}56^{\circ} 32.63 \mathrm{~N} 14^{\circ} 30.92 \mathrm{~W}- \\
56^{\circ} 33.97 \mathrm{~N} 14^{\circ} 28.78 \mathrm{~W}\end{array}$ & 198-202 & 30-Aug-11 & 12 \\
\hline Ptilella grayi n. sp. & $\begin{array}{l}\text { Rockall Haddock } \\
\text { Survey } 2011\end{array}$ & 0911S (S11427) & $\begin{array}{c}\text { Rockall Bank, NE } \\
\text { Atlantic }\end{array}$ & $\begin{array}{l}56^{\circ} 35.18 \mathrm{~N} 14^{\circ} 24.27 \mathrm{~W}- \\
56^{\circ} 36.48 \mathrm{~N} 14^{\circ} 22.06 \mathrm{~W}\end{array}$ & 204-209 & 30-Aug-11 & 2 \\
\hline Ptilella grayi $\mathrm{n} . \mathrm{sp}$. & $\begin{array}{l}\text { Rockall Haddock } \\
\text { Survey } 2011\end{array}$ & 0911S (S11430) & $\begin{array}{c}\text { Rockall Bank, NE } \\
\text { Atlantic }\end{array}$ & $\begin{array}{l}56^{\circ} 42.54 \mathrm{~N} 14^{\circ} 03.67 \mathrm{~W}- \\
56^{\circ} 43.71 \mathrm{~N} 14^{\circ} 01.29 \mathrm{~W}\end{array}$ & $251-255$ & 30-Aug-11 & 1 \\
\hline Ptilella grayi $\mathrm{n} . \mathrm{sp}$. & $\begin{array}{l}\text { Rockall Haddock } \\
\text { Survey } 2011\end{array}$ & 0911S (S11432) & $\begin{array}{c}\text { Rockall Bank, NE } \\
\text { Atlantic }\end{array}$ & $\begin{array}{l}57^{\circ} 02.48 \mathrm{~N} 13^{\circ} 52.08 \mathrm{~W}- \\
57^{\circ} 03.75 \mathrm{~N} 13^{\circ} 49.62 \mathrm{~W}\end{array}$ & $182-186$ & 30-Aug-11 & 1 \\
\hline Ptilella grayi $\mathrm{n} . \mathrm{sp}$. & $\begin{array}{l}\text { Rockall Anglerfish } \\
\text { Survey } 2012\end{array}$ & 0412S (S12141) & $\begin{array}{c}\text { Rockall Bank, NE } \\
\text { Atlantic }\end{array}$ & $\begin{array}{l}55^{\circ} 51.10 \mathrm{~N} 15^{\circ} 19.53 \mathrm{~W}- \\
55^{\circ} 52.24 \mathrm{~N} 15^{\circ} 13.35 \mathrm{~W}\end{array}$ & $365-375$ & 14-Apr-12 & 1 \\
\hline Ptilella grayi $\mathrm{n} . \mathrm{sp}$. & $\begin{array}{l}\text { Rockall Anglerfish } \\
\text { Survey } 2012\end{array}$ & 0412S (S12145) & $\begin{array}{c}\text { Rockall Bank, NE } \\
\text { Atlantic }\end{array}$ & $\begin{array}{l}56^{\circ} 32.34 \mathrm{~N} 14^{\circ} 55.91 \mathrm{~W}- \\
56^{\circ} 35.17 \mathrm{~N} 15^{\circ} 00.02 \mathrm{~W}\end{array}$ & $195-225$ & 15-Apr-12 & 3 \\
\hline Ptilella grayi $\mathrm{n} . \mathrm{sp}$. & $\begin{array}{l}\text { Rockall Anglerfish } \\
\text { Survey } 2012\end{array}$ & 0412S (S12146) & $\begin{array}{c}\text { Rockall Bank, NE } \\
\text { Atlantic }\end{array}$ & $\begin{array}{l}56^{\circ} 53.19 \mathrm{~N} 14^{\circ} 44.00 \mathrm{~W}- \\
56^{\circ} 55.71 \mathrm{~N} 14^{\circ} 39.29 \mathrm{~W}\end{array}$ & 179-192 & 15-Apr-12 & 1 \\
\hline Ptilella grayi $\mathrm{n} . \mathrm{sp}$. & OFFCON 2012 & 0712S (S12287) & $\begin{array}{c}\text { Rockall Bank, NE } \\
\text { Atlantic }\end{array}$ & $\begin{array}{l}57^{\circ} 22.33 \mathrm{~N} 13^{\circ} 54.87 \mathrm{~W}- \\
57^{\circ} 21.36 \mathrm{~N} 13^{\circ} 57.73 \mathrm{~W}\end{array}$ & $146-152$ & 15-Apr-12 & 1 \\
\hline Ptilella grayi $\mathrm{n} . \mathrm{sp}$. & $\begin{array}{l}\text { Rockall Haddock } \\
\text { Survey } 2013\end{array}$ & $1113 S$ (S13304) & $\begin{array}{l}\text { Rockall Bank, NE } \\
\text { Atlantic }\end{array}$ & $\begin{array}{l}56^{\circ} 43.65 \mathrm{~N} 14^{\circ} 14.44 \mathrm{~W}- \\
56^{\circ} 41.83 \mathrm{~N} 14^{\circ} 14.62 \mathrm{~W}\end{array}$ & $196-203$ & 14-Sep-13 & 2 \\
\hline Ptilella grayi $\mathrm{n} . \mathrm{sp}$. & $\begin{array}{l}\text { Rockall Haddock } \\
\text { Survey } 2013\end{array}$ & $1113 S$ (S13305) & $\begin{array}{c}\text { Rockall Bank, NE } \\
\text { Atlantic }\end{array}$ & $\begin{array}{l}56^{\circ} 36.15 \mathrm{~N} 14^{\circ} 22.46 \mathrm{~W}- \\
56^{\circ} 34.79 \mathrm{~N} 14^{\circ} 24.46 \mathrm{~W}\end{array}$ & 206-209 & 14-Sep-13 & 1 \\
\hline Ptilella grayi $\mathrm{n} . \mathrm{sp}$. & $\begin{array}{l}\text { Rockall Haddock } \\
\text { Survey } 2013\end{array}$ & $1113 S$ (S13306) & $\begin{array}{c}\text { Rockall Bank, NE } \\
\text { Atlantic }\end{array}$ & $\begin{array}{l}56^{\circ} 36.05 \mathrm{~N} 14^{\circ} 30.02 \mathrm{~W}- \\
56^{\circ} 35.75 \mathrm{~N} 14^{\circ} 33.40 \mathrm{~W}\end{array}$ & 196-199 & 14-Sep-13 & 6 \\
\hline Ptilella grayi $\mathrm{n} . \mathrm{sp}$. & $\begin{array}{l}\text { Rockall Haddock } \\
\text { Survey } 2013\end{array}$ & $1113 S$ (S13307) & $\begin{array}{c}\text { Rockall Bank, NE } \\
\text { Atlantic }\end{array}$ & $\begin{array}{l}56^{\circ} 40.01 \mathrm{~N} 14^{\circ} 39.58 \mathrm{~W}- \\
56^{\circ} 39.38 \mathrm{~N} 14^{\circ} 40.49 \mathrm{~W}\end{array}$ & 195-198 & 14-Sep-13 & 2 \\
\hline Ptilella grayi $\mathrm{n} . \mathrm{sp}$. & $\begin{array}{l}\text { Rockall Anglerfish } \\
\text { Survey } 2013\end{array}$ & 1413S (S13371) & $\begin{array}{c}\text { Rockall Bank, NE } \\
\text { Atlantic }\end{array}$ & $\begin{array}{l}56^{\circ} 36.59 \mathrm{~N} 14^{\circ} 26.65 \mathrm{~W}- \\
56^{\circ} 35.81 \mathrm{~N} 14^{\circ} 32.89 \mathrm{~W}\end{array}$ & 197-199 & $24-O c t-13$ & 82 \\
\hline Ptilella grayi n. sp. & $\begin{array}{l}\text { Rockall Anglerfish } \\
\text { Survey } 2013\end{array}$ & 1413S (S13372) & $\begin{array}{c}\text { Rockall Bank, NE } \\
\text { Atlantic }\end{array}$ & $\begin{array}{l}56^{\circ} 55.42 \mathrm{~N} 14^{\circ} 31.33 \mathrm{~W}- \\
56^{\circ} 58.65 \mathrm{~N} 14^{\circ} 28.61 \mathrm{~W}\end{array}$ & $179-188$ & $24-O c t-13$ & 2 \\
\hline Ptilella grayi n. sp. & $\begin{array}{l}\text { Rockall Anglerfish } \\
\text { Survey } 2013\end{array}$ & 1413S (S13373) & $\begin{array}{c}\text { Rockall Bank, NE } \\
\text { Atlantic }\end{array}$ & $\begin{array}{l}57^{\circ} 10.17 \mathrm{~N} 14^{\circ} 11.27 \mathrm{~W}- \\
57^{\circ} 12.81 \mathrm{~N} 14^{\circ} 06.85 \mathrm{~W}\end{array}$ & $165-171$ & 24-Oct-13 & 4 \\
\hline Ptilella $g$ & $\begin{array}{l}\text { Rockall Anglerfish } \\
\text { Survey } 2014\end{array}$ & 0414S (S14141) & $\begin{array}{c}\text { Rockall Bank, NE } \\
\text { Atlantic }\end{array}$ & $\begin{array}{l}56^{\circ} 25.40 \mathrm{~N} 14^{\circ} 57.37 \mathrm{~W}- \\
56^{\circ} 26.56 \mathrm{~N} 14^{\circ} 54.75 \mathrm{~W}\end{array}$ & -212 & 4-Apr-14 & 2 \\
\hline Ptilella grayi $\mathrm{n} . \mathrm{sp}$. & $\begin{array}{l}\text { Rockall Anglerfish } \\
\text { Survey } 2014\end{array}$ & 0414S (S14144) & $\begin{array}{c}\text { Rockall Bank, NE } \\
\text { Atlantic }\end{array}$ & $\begin{array}{l}56^{\circ} 41.94 \mathrm{~N} 14^{\circ} 32.66 \mathrm{~W}- \\
56^{\circ} 45.50 \mathrm{~N} 14^{\circ} 32.42 \mathrm{~W}\end{array}$ & 193-199 & 15-Apr-14 & 2 \\
\hline Ptilella grayi $\mathrm{n} . \mathrm{sp}$. & $\begin{array}{l}\text { Rockall Anglerfish } \\
\text { Survey } 2015\end{array}$ & 0415S (S15142) & $\begin{array}{c}\text { Rockall Bank, NE } \\
\text { Atlantic }\end{array}$ & $\begin{array}{l}56^{\circ} 36.04 \mathrm{~N} 14^{\circ} 14.27 \mathrm{~W}- \\
56^{\circ} 32.91 \mathrm{~N} 14^{\circ} 16.67 \mathrm{~W}\end{array}$ & $260-299$ & 11-Apr-15 & 1 \\
\hline
\end{tabular}




\begin{tabular}{|c|c|c|c|c|c|c|c|}
\hline Species & Cruise & Cruise no (haul) & Area & $\begin{array}{l}\text { Coordinates } \\
\text { Start - Stop }\end{array}$ & $\begin{array}{l}\text { Depth } \\
\text { range }(\mathrm{m})\end{array}$ & Date & $\begin{array}{l}\text { No. colo- } \\
\text { nies }\end{array}$ \\
\hline Ptilella grayi $\mathrm{n} . \mathrm{sp}$. & $\begin{array}{l}\text { Rockall Anglerfish } \\
\text { Survey } 2015\end{array}$ & 0415S (S15143) & $\begin{array}{c}\text { Rockall Bank, NE } \\
\text { Atlantic }\end{array}$ & $\begin{array}{l}56^{\circ} 36.27 \mathrm{~N} 14^{\circ} 26.94 \mathrm{~W}- \\
56^{\circ} 35.43 \mathrm{~N} 14^{\circ} 32.96 \mathrm{~W}\end{array}$ & 194-205 & 2-Apr-15 & 17 \\
\hline Ptilella grayi $\mathrm{n} . \mathrm{sp}$. & $\begin{array}{l}\text { Rockall Anglerfish } \\
\text { Survey } 2015\end{array}$ & 0415S (S15144) & $\begin{array}{c}\text { Rockall Bank, NE } \\
\text { Atlantic }\end{array}$ & $\begin{array}{l}56^{\circ} 29.97 \mathrm{~N} 14^{\circ} 21.34 \mathrm{~W}- \\
56^{\circ} 27.17 \mathrm{~N} 14^{\circ} 24.64 \mathrm{~W}\end{array}$ & $281-287$ & 2-Apr-15 & 3 \\
\hline Ptilella grayi $\mathrm{n} . \mathrm{sp}$. & $\begin{array}{l}\text { Rockall Anglerfish } \\
\text { Survey } 2015\end{array}$ & 0415S (S15157) & $\begin{array}{c}\text { Rockall Bank, NE } \\
\text { Atlantic }\end{array}$ & $\begin{array}{l}56^{\circ} 25.35 \mathrm{~N} 14^{\circ} 56.29 \mathrm{~W}- \\
56^{\circ} 27.76 \mathrm{~N} 14^{\circ} 51.81 \mathrm{~W}\end{array}$ & $204-214$ & 14-Apr-15 & 1 \\
\hline Ptilella grayi $\mathrm{n} . \mathrm{sp}$. & $\begin{array}{l}\text { Rockall Anglerfish } \\
\text { Survey } 2015\end{array}$ & 0415S (S15159) & $\begin{array}{c}\text { Rockall Bank, NE } \\
\text { Atlantic }\end{array}$ & $\begin{array}{l}56^{\circ} 34.02 \mathrm{~N} 15^{\circ} 13.28 \mathrm{~W}- \\
56^{\circ} 30.69 \mathrm{~N} 15^{\circ} 15.78 \mathrm{~W}\end{array}$ & $266-289$ & 14-Apr-15 & 1 \\
\hline Ptilella grayi n. sp. & $\begin{array}{l}\text { Rockall Haddock } \\
\text { Survey } 2015\end{array}$ & $1115 \mathrm{~S}(\mathrm{~S} 15351)$ & $\begin{array}{c}\text { Rockall Bank, NE } \\
\text { Atlantic }\end{array}$ & $\begin{array}{l}56^{\circ} 35.93 \mathrm{~N} 14^{\circ} 31.35 \mathrm{~W}- \\
56^{\circ} 36.48 \mathrm{~N} 14^{\circ} 28.27 \mathrm{~W}\end{array}$ & $196-198$ & 31-Aug-15 & 1 \\
\hline Ptilella grayi $\mathrm{n} . \mathrm{sp}$. & $\begin{array}{l}\text { Rockall Haddock } \\
\text { Survey } 2015\end{array}$ & $1115 \mathrm{~S}$ (S15352) & $\begin{array}{c}\text { Rockall Bank, NE } \\
\text { Atlantic }\end{array}$ & $\begin{array}{l}56^{\circ} 36.95 \mathrm{~N} 14^{\circ} 16.25 \mathrm{~W}- \\
56^{\circ} 38.10 \mathrm{~N} 14^{\circ} 13.72 \mathrm{~W}\end{array}$ & $226-231$ & 15 & 1 \\
\hline Ptilella grayi $\mathrm{n} . \mathrm{sp}$. & $\begin{array}{l}\text { Rockall Haddock } \\
\text { Survey } 2015\end{array}$ & $1115 \mathrm{~S}$ (S15356) & $\begin{array}{c}\text { Rockall Bank, NE } \\
\text { Atlantic }\end{array}$ & $\begin{array}{l}57^{\circ} 02.91 \mathrm{~N} 13^{\circ} 25.79 \mathrm{~W}- \\
57^{\circ} 01.49 \mathrm{~N} 13^{\circ} 27.53 \mathrm{~W}\end{array}$ & $270-278$ & 01-Sep-15 & 1 \\
\hline Ptilella grayi $\mathrm{n} . \mathrm{sp}$. & $\begin{array}{l}\text { Rockall Anglerfish } \\
\text { Survey } 2016\end{array}$ & 0416S (S16137) & $\begin{array}{c}\text { Rockall Bank, NE } \\
\text { Atlantic }\end{array}$ & $\begin{array}{l}57^{\circ} 36.48 \mathrm{~N} 12^{\circ} 57.47 \mathrm{~W}- \\
57^{\circ} 34.60 \mathrm{~N} 12^{\circ} 57.59 \mathrm{~W}\end{array}$ & $280-290$ & 09-Apr-16 & 1 \\
\hline Ptilella grayi n. sp. & $\begin{array}{l}\text { Rockall Anglerfish } \\
\text { Survey } 2016\end{array}$ & 0416S (S16164) & $\begin{array}{c}\text { Rockall Bank, NE } \\
\text { Atlantic }\end{array}$ & $\begin{array}{l}56^{\circ} 15.82 \mathrm{~N} 16^{\circ} 14.36 \mathrm{~W}- \\
56^{\circ} 12.51 \mathrm{~N} 16^{\circ} 15.49 \mathrm{~W}\end{array}$ & $358-389$ & 13-Apr-16 & 2 \\
\hline Ptilella grayi $\mathrm{n} . \mathrm{sp}$. & $\begin{array}{l}\text { Rockall Haddock } \\
\text { Survey } 2016\end{array}$ & 1216S (S16365) & $\begin{array}{c}\text { Rockall Bank, NE } \\
\text { Atlantic }\end{array}$ & $\begin{array}{l}56^{\circ} 33.53 \mathrm{~N} 14 \\
56^{\circ} 32.22 \mathrm{~N} 1\end{array}$ & 199-201 & 05-Sep-16 & 3 \\
\hline Ptilella grayi $\mathrm{n} . \mathrm{sp}$. & $\begin{array}{l}\text { Rockall Haddock } \\
\text { Survey } 2016\end{array}$ & 1216S (S16366) & $\begin{array}{c}\text { Rockall Bank, NE } \\
\text { Atlantic }\end{array}$ & $\begin{array}{l}56^{\circ} 46.45 \mathrm{~N} 14^{\circ} 27.75 \mathrm{~W}- \\
56^{\circ} 44.81 \mathrm{~N} 14^{\circ} 29.19 \mathrm{~W}\end{array}$ & $186-193$ & 05-Sep-16 & 3 \\
\hline Ptilella grayi n. sp. & $\begin{array}{l}\text { Rockall Haddock } \\
\text { Survey } 2016\end{array}$ & 1216S (S16368) & $\begin{array}{c}\text { Rockall Bank, NE } \\
\text { Atlantic }\end{array}$ & $\begin{array}{l}56^{\circ} 47.22 \mathrm{~N} 14^{\circ} 05.67 \mathrm{~W}- \\
56^{\circ} 45.63 \mathrm{~N} 14^{\circ} 07.23 \mathrm{~W}\end{array}$ & $193-200$ & $05-\mathrm{Se}$ & 1 \\
\hline Ptilella grayi $\mathrm{n} . \mathrm{sp}$. & $\begin{array}{l}\text { Rockall Haddock } \\
\text { Survey } 2016\end{array}$ & 1216S (S16372) & $\begin{array}{c}\text { Rockall Bank, NE } \\
\text { Atlantic }\end{array}$ & $\begin{array}{l}57^{\circ} 07.74 \mathrm{~N} 13^{\circ} 23.21 \mathrm{~W}- \\
57^{\circ} 06.31 \mathrm{~N} 13^{\circ} 25.09 \mathrm{~W}\end{array}$ & $215-2$ & $06-\mathrm{S}$ & 1 \\
\hline Ptilella grandis & $\begin{array}{l}\text { Deepwater Time } \\
\text { Series } 2008\end{array}$ & 1108S (S08385) & $\begin{array}{l}\text { Donegal Slope, NE } \\
\text { Atlantic }\end{array}$ & $\begin{array}{l}55^{\circ} 13.79 \mathrm{~N} 10^{\circ} 08.87 \mathrm{~W}- \\
55^{\circ} 08.49 \mathrm{~N} 10^{\circ} 10.66 \mathrm{~W}\end{array}$ & 45 & 14-Sep-08 & 1 \\
\hline Ptilella grandis & OFFCON 2011 & 0711S (S11264) & $\begin{array}{c}\text { Rockall Basin, NE } \\
\text { Atlantic }\end{array}$ & $\begin{array}{l}57^{\circ} 36.37 \mathrm{~N} 12^{\circ} 36.66 \mathrm{~W}- \\
57^{\circ} 35.94 \mathrm{~N} 12^{\circ} 36.98 \mathrm{~W}\end{array}$ & $1601-1605$ & 30-Jun-11 & 1 \\
\hline Ptilella grandis & $\begin{array}{l}\text { North Sea Angler- } \\
\text { fish Survey } 2016\end{array}$ & 0412S (S12220) & $\begin{array}{l}\text { S Norwegian Sea, } \\
\text { NE Atlantic }\end{array}$ & $\begin{array}{l}61^{\circ} 55.05{\mathrm{~N} 02^{\circ} 28.94 \mathrm{E}-}_{61^{\circ} 52.66 \mathrm{~N} 02^{\circ} 34.22 \mathrm{E}}\end{array}$ & $380-404$ & 29-Apr-12 & 1 \\
\hline Ptilella grandis & MoreDeep 2014 & 1314S (S14379) & $\begin{array}{l}\text { Rosemary Seamount, } \\
\text { NE Atlantic }\end{array}$ & $\begin{array}{l}59^{\circ} 26.55 \mathrm{~N} 10^{\circ} 09.34 \mathrm{~W}- \\
59^{\circ} 26.60 \mathrm{~N} 10^{\circ} 02.14 \mathrm{~W}\end{array}$ & $859-889$ & 15-Sep-14 & 1 \\
\hline Ptilella grandis & MoreDeep 2014 & & $\begin{array}{l}\text { Rosemary Seamount, } \\
\text { NE Atlantic }\end{array}$ & $\begin{array}{l}59^{\circ} 05.37 \mathrm{~N} 09^{\circ} 54.16 \mathrm{~W}- \\
59^{\circ} 06.40 \mathrm{~N} 09^{\circ} 51.58 \mathrm{~W}\end{array}$ & $1052-1075$ & 16-Sep-14 & 1 \\
\hline Ptilella grandis & $\begin{array}{l}\text { Rockall Anglerfish } \\
\text { Survey } 2016\end{array}$ & & $\begin{array}{l}\text { West Rockall Bank, } \\
\text { NE Atlantic }\end{array}$ & $\begin{array}{l}56^{\circ} 57.12 \mathrm{~N} 14^{\circ} 15.98 \mathrm{~W}- \\
56^{\circ} 56.60 \mathrm{~N} 14^{\circ} 21.78 \mathrm{~W}\end{array}$ & $723-761$ & 11-Apr-16 & 1 \\
\hline Ptilella grandis & $\begin{array}{l}\text { Rockall Anglerfish } \\
\text { Survey } 2016\end{array}$ & 0416S (S16155) & $\begin{array}{l}\text { West Rockall Bank, } \\
\text { NE Atlantic }\end{array}$ & $\begin{array}{l}56^{\circ} 36.27 \mathrm{~N} 14^{\circ} 26.94 \mathrm{~W}- \\
56^{\circ} 35.43 \mathrm{~N} 14^{\circ} 32.96 \mathrm{~W}\end{array}$ & $682-727$ & 11-Apr-16 & 1 \\
\hline Ptilella grandis & MoreDeep 2016 & 1316S (S16379) & $\begin{array}{l}\text { Rosemary Seamount, } \\
\text { NE Atlantic }\end{array}$ & $\begin{array}{l}59^{\circ} 06.16 \mathrm{~N} 09^{\circ} 52.17 \mathrm{~W}- \\
59^{\circ} 05.16 \mathrm{~N} 09^{\circ} 54.75 \mathrm{~W}\end{array}$ & $1061-1100$ & 19-Sep-16 & 2 \\
\hline
\end{tabular}

Table S2. - Nucleotide substitution implying amino acid changes in the mitochondrial loci mtMutS and Coxl, between the sequences of Ptilella and Pennatula used in the molecular analyses, once homologous sites of a datamatrix including Ptilella and Pennatula sequences are aligned (see Table 2 and Fig. 5).

\begin{tabular}{|c|c|c|c|c|c|}
\hline & Loci & $\begin{array}{l}\text { Nucleotide } \\
\text { positions }\end{array}$ & $\begin{array}{l}\text { Nucleotide triplet } \\
\text { Ptilella / Pennatula }\end{array}$ & Aa position & $\begin{array}{c}\text { Aa substitution } \\
\text { Ptilella / Pennatula }\end{array}$ \\
\hline \multirow{6}{*}{\multicolumn{2}{|c|}{$m t M u t S$}} & 34 & ATG / GTA $(G T G)^{1}$ & 12 & $\operatorname{Met}(\mathrm{M}) / \mathrm{Val}(\mathrm{V})$ \\
\hline & & 74 & CCG / CAG & 25 & Pro (P) / Glm (Q) \\
\hline & & 164 & GCT / GTT & 55 & Ala (A) / Val (V) \\
\hline & & 197 & GGA / GAA & 66 & Gly (G) / Glu (E) \\
\hline & & 199 & GTA / ATA & 67 & $\mathrm{Val}(\mathrm{V}) / \mathrm{Ile}(\mathrm{I}$ \\
\hline & & 533 & GCC / GTC & 181 & Ala (A) / Val (V) \\
\hline \multirow{7}{*}{\multicolumn{2}{|c|}{ Coxl }} & 226 & TTG / ATG & 76 & Leu (L) / Met (M) \\
\hline & & 271 & TCA / GCA & 91 & Ser (S) / Ala (A) \\
\hline & & 371 & $\mathrm{GCG}(\mathrm{GCA})^{2} / \mathrm{GTA}$ & 124 & Ala (A) / Val (V) \\
\hline & & 388 & ATT / CTT & 130 & Ile (I) / Leu (L) \\
\hline & & 439 & AGT / CTA(TTA) & 147 & Met (M) / Leu (L) \\
\hline & & 568 & GTA / ATA & 190 & $\mathrm{Val}(\mathrm{V}) / \mathrm{Ile}(\mathrm{I})$ \\
\hline & & 574 & GTT / ATT & 192 & Val (V) / Ile (I) \\
\hline
\end{tabular}

${ }^{1}$ and ${ }^{2}$, the third base of this triplet is a variable position within that genus (interspecific variability). The substitutions implying intergeneric differences occur in the first base of the triplet in 1 , but in the second base in 2 . 
Table S3. - Nucleotide and amino acid differences in the mitochondrial loci mtMutS and Coxl, and nucleotide differences in the nuclear $28 S$ between Ptilella grayi n. sp. and Pt. grandis. Based on a datamatrix including only Ptiella and Pennatula species (see Table 2 and Fig. 5).

\begin{tabular}{ccc}
\hline \multirow{2}{*}{ Loci } & $\begin{array}{c}\text { Nucleotide (position) } \\
\text { Pt. } \text { grayi / Pt. grandis }\end{array}$ & $\begin{array}{c}\text { Amino acid (position) } \\
\text { Pt. grayi / Pt. grandis }\end{array}$ \\
\hline \multirow{2}{*}{ tMutS } & $(249) \mathrm{A} / \mathrm{C}$ & (83) Met / Ile \\
& $(672) \mathrm{C} / \mathrm{A}$ & $(225) \mathrm{Phe} / \mathrm{Leu}$ \\
Cox1 & $(372) \mathrm{A} / \mathrm{G}$ & $(124) \mathrm{Ala} / \mathrm{Ala}$ \\
& $(624) \mathrm{C} / \mathrm{A}$ & \\
$28 S$ & $(166) \mathrm{C} / \mathrm{A}$ & \\
& $(210) \mathrm{A} / \mathrm{G}$ & \\
& $(519) \mathrm{G} / \mathrm{C}$ & \\
\hline
\end{tabular}
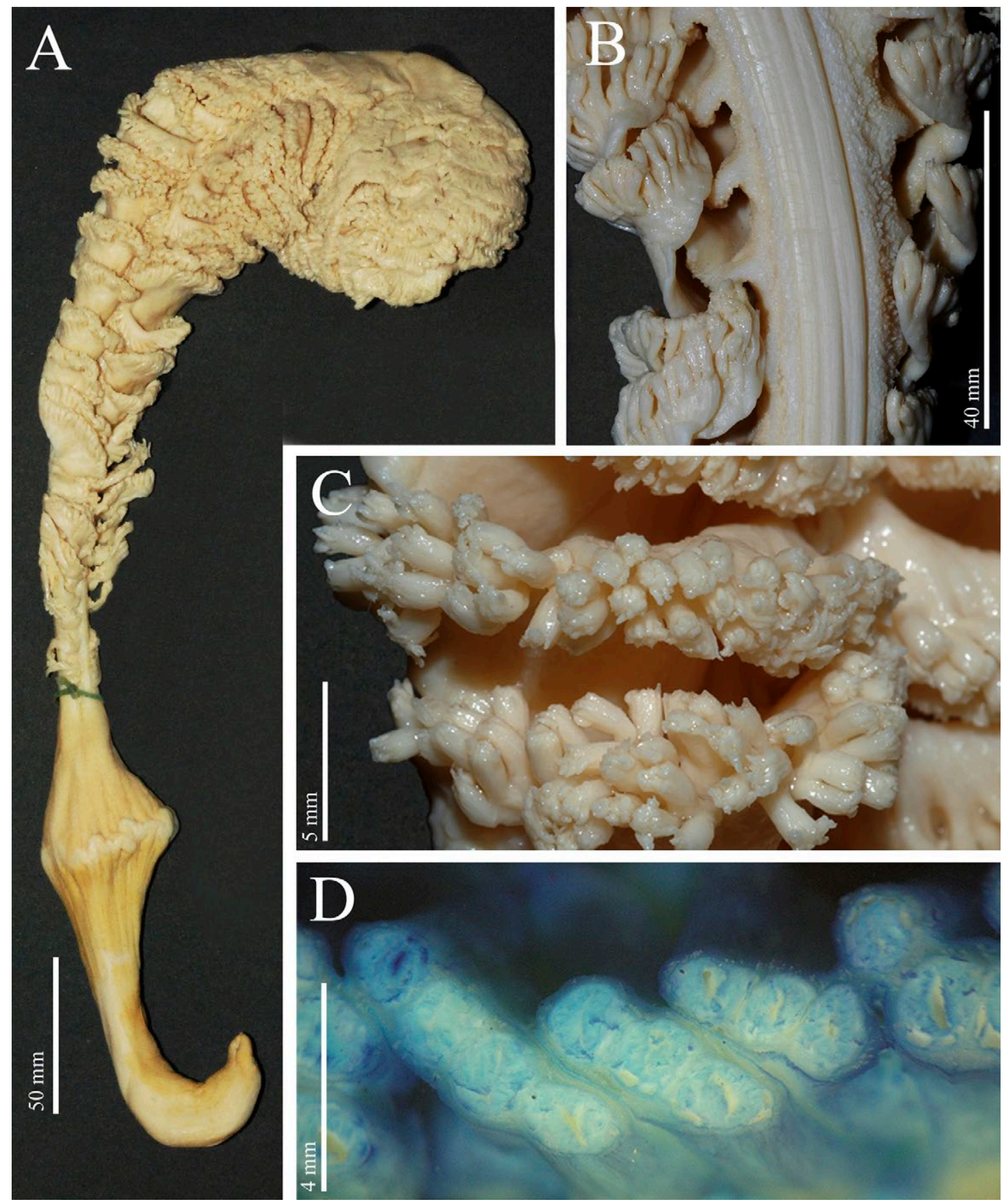

Fig. S1. - Ptilella grayi n. sp. Paratype (NMS.Z.2019.2.3). A, whole colony; B, dorsal view of polyp leaves and naked dorsal track showing the location of mesozooids; C, detail of autozooids on the ventral edge of the polyp leaves; D, detail of oblique rows of autozooids, sectioned basally, stained with methylene blue to increase contrast. 

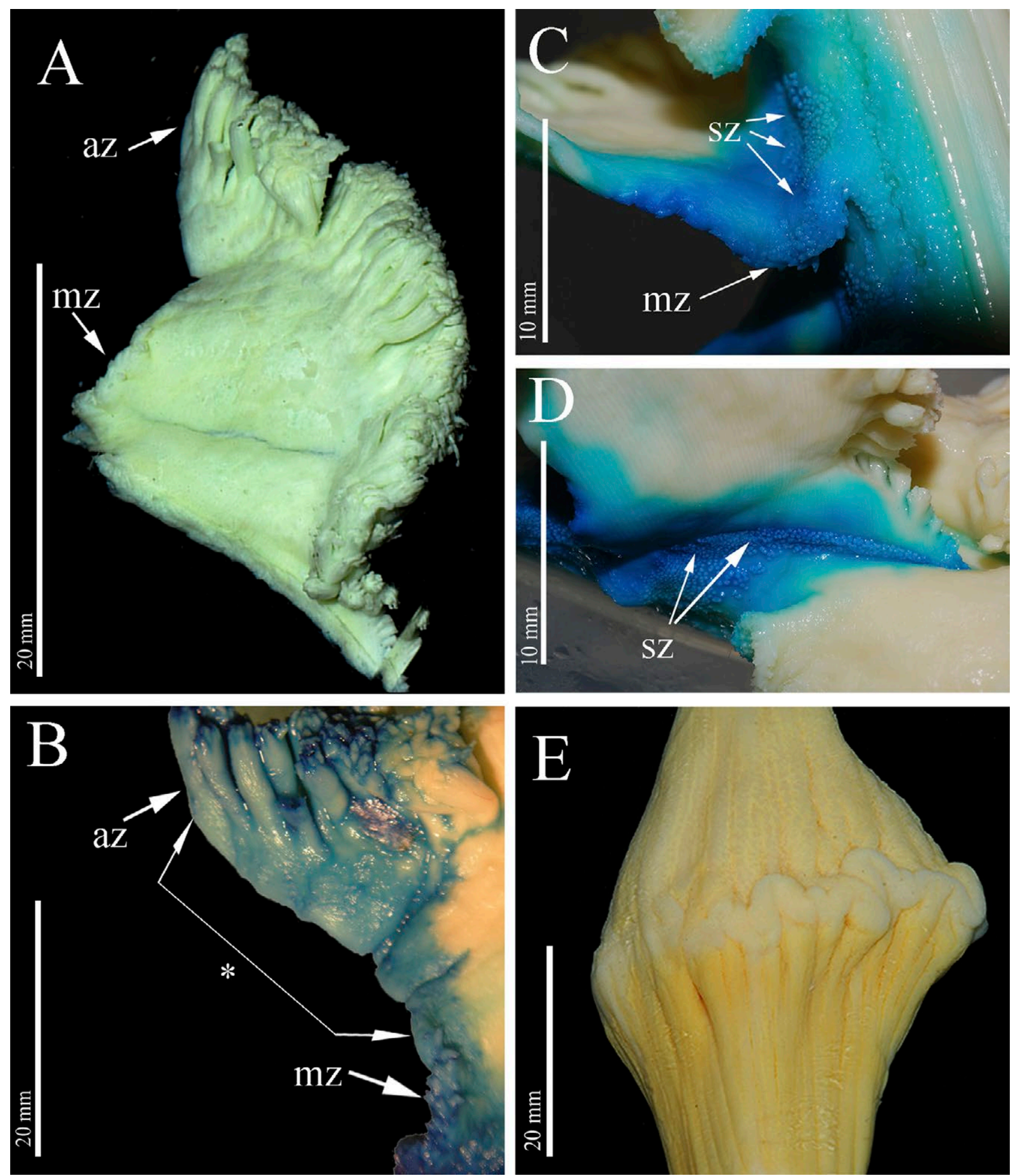

Fig. S2. - Ptilella grayi n. sp. Paratype (NMS.Z.2019.2.3). A, polyp-leaf sectioned from the base, lateral view; B, detail of dorsal area of a polyp-leaf showing autozooids (az) and mesozooids (mz), and distal area free of zooids $(*)$; C, detail of dorsal basal part of polyp leaves showing siphonozooids (sz) and mesozooids (mz); D, detail of arrangement of siphonozooids ( $\mathrm{Cz}$ ) in pad at the base of a polyp leaf; E, distinctive thickening at the rachis-peduncle limit and edged ring. B, C and D stained with methylene blue to increase contrast. 


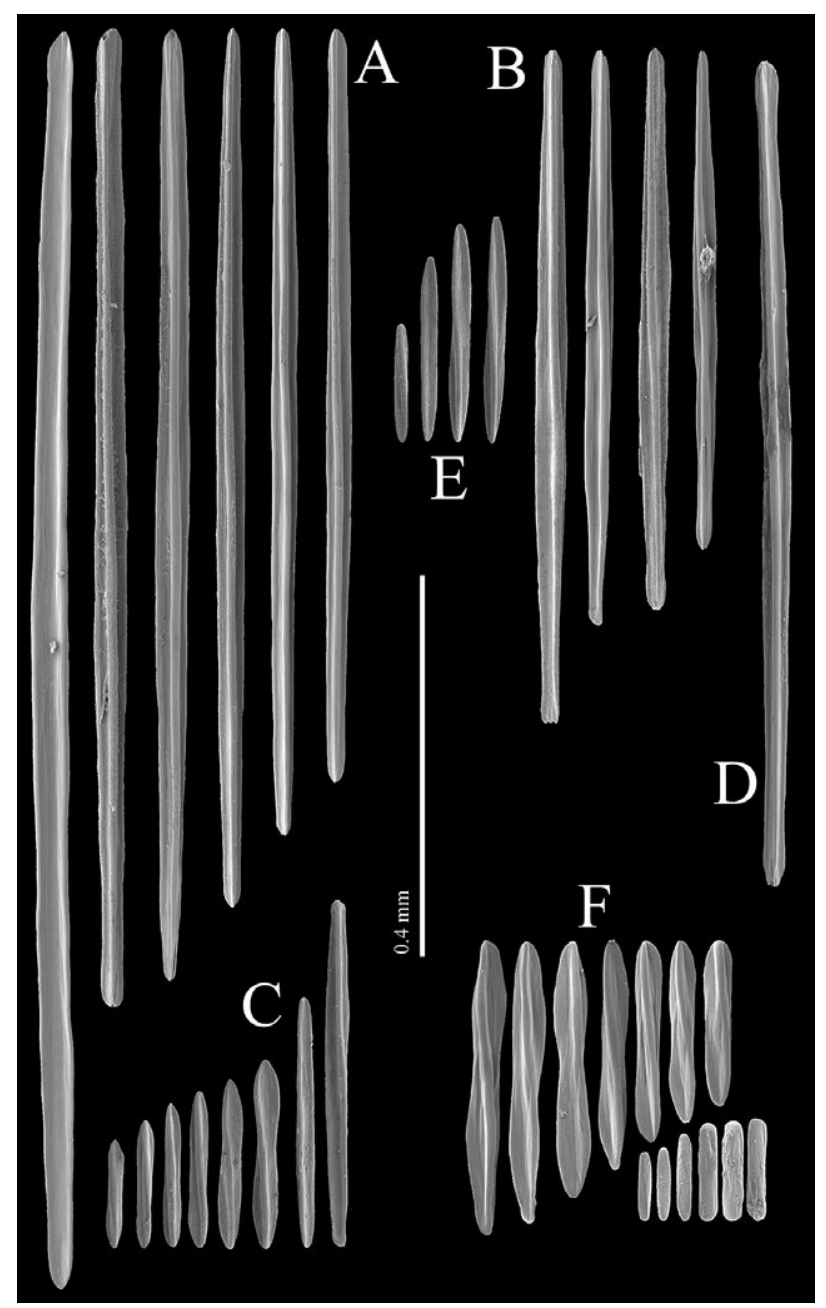

Fig. S3. - Ptilella grayi n. sp. Paratype (NMS.Z.2019.2.3). SEM photographs of sclerites. A, calyces; B, mesozooids; C, siphonozooids; D, polyp leaves; E, dorsal track; F, rachis-peduncle limit, above edged ring (upper row) and below edged ring (lower row). 